\title{
Mechanisms of Postprandial Protein Accretion in Human Skeletal Muscle Insight from Leucine and Phenylalanine Forearm Kinetics
}

\author{
Paolo Tessari, ${ }^{*}$ Michela Zanetti, ${ }^{\star}$ Rocco Barazzoni, ${ }^{\star}$ Monica Vettore, ${ }^{\star}$ and Flavio Michielan‡ \\ *Department of Metabolic Diseases and of ${ }^{\ddagger}$ Anesthesiology and Intensive Care, University of Padova, 35128 Padova, Italy
}

\begin{abstract}
The relative role of protein synthesis and degradation in determining postprandial net protein deposition in human muscle is not known. To this aim, we studied forearm leucine and phenylalanine turnover by combining the arteriovenous catheterization with tracer infusions, before and following a $4 \mathrm{~h}$ administration of a mixed meal in normal volunteers. Forearm amino acid kinetics were assessed in both whole blood and plasma. Fasting forearm protein degradation exceeded synthesis $(P<0.01)$ using either tracer, indicating net muscle protein loss. The net negative forearm protein balance was quantitatively similar in whole blood and in plasma. After the meal, forearm proteolysis was suppressed $(P<0.05-<0.03)$, while forearm protein synthesis was stimulated $(P<0.05-<0.01)$. However, stimulation of protein synthesis was greater $(P<0.05-<0.01)$ in whole blood (leucine data: $+50.4 \pm 7.8 \mathrm{nmol} / \mathrm{min} \times 100 \mathrm{ml}$ of forearm; phenylalanine data: $+30.4 \pm 11.6$ ) than in plasma (leucine data: $+\mathbf{1 7 . 8} \pm 5.6 \mathrm{nmol} / \mathrm{min} \times 100 \mathrm{ml}$ of forearm; phenylalanine data: $+5.7 \pm 2.1$ ). Consequently, the increment of net amino acid balance was approximately two to fourfold greater $(P<0.04-<0.03)$ in whole blood than in plasma. In conclusion, meal ingestion stimulates forearm protein deposition through both enhanced protein synthesis and inhibited proteolysis. Plasma data underestimate net postprandial forearm protein synthesis, suggesting a key role of red blood cells and/or of blood mass in mediating mealenhanced protein accretion. (J. Clin. Invest. 1996. 98:13611372.) Key words: postprandial state - forearm protein synthesis $\bullet$ forearm proteolysis $\bullet$ leucine oxidation
\end{abstract}

\section{Introduction}

Conservation of body proteins is attained through mealinduced enhancement of tissue protein deposition, which counteracts the protein loss of interprandial periods $(1,2)$. Net protein deposition in tissues is the result of a balance between degradation and synthesis. Knowledge of response to meal of both these processes is important, firstly to understand the normal physiological mechanisms, secondly to investigate pathological states which may selectively alter postprandial proteolysis, protein synthesis, or both.

Address correspondence to Paolo Tessari M.D., Cattedra di Malattie del Ricambio, Via Giustiniani 2, 35128 Padova, Italy. FAX: 011-3949-875-4179.

Received for publication 3 January 1996 and accepted in revised form 13 June 1996.

J. Clin. Invest.

(C) The American Society for Clinical Investigation, Inc.

0021-9738/96/09/1361/12 \$2.00

Volume 98, Number 6, September 1996, 1361-1372
Several studies in humans have shown that meal ingestion is accompanied by both an increase of whole body protein synthesis and a suppression of protein degradation (3-11). However, the response to meal of protein kinetics in individual human body tissues is far less known. Synthesis of albumin, i.e., the most abundant plasma protein, was stimulated by a mixed meal (11). It is surprising, however, that possible changes of postprandial protein turnover occurring in skeletal muscle, i.e., the most abundant deposit of body proteins (12), have been scarcely investigated in humans. Studies performed using tracer amino acid(s) incorporation into mixed skeletal muscle proteins through needle biopsy, have shown either a stimulation $(6,13)$ or minor and insignificant changes (14) of muscle fractional protein synthesis following a meal. Besides these discrepancies, muscle protein degradation was not simultaneously measured in these studies, because of the intrinsic limitations of the biopsy method there used. Thus, whether muscle proteolysis is suppressed after a meal, in analogy to what is observed at the whole body level, has never been investigated.

Muscle protein synthesis and degradation can be simultaneously determined in humans using the forearm and/or leg catheterization technique, combined with isotope infusions (15-20). Phenylalanine, an essential amino acid that is neither catabolized nor produced de novo by forearm, i.e., muscle, tissues $(21,22)$ has been widely used as a tracer. Leucine, another essential amino acid, has been employed too, provided that arteriovenous measurements of all its metabolic products are performed, since leucine is also degraded by muscle tissues (23-27).

In this study, we report on the effects of mixed meal ingestion on muscle protein synthesis and degradation in the human forearm, measured simultaneously using both a phenylalanine and an "intracellular" leucine tracer model (27). Furthermore, since red blood cells may also contribute to organ amino acid exchange $(28,29)$, all kinetic rates were calculated from measurements of substrate and isotope concentrations, as well as of forearm flow, performed both in whole blood and in plasma.

\section{Methods}

Isotopes. $\mathrm{L}-\left[1-{ }^{14} \mathrm{C}\right]$ leucine $(\mathrm{sp}$ act $\sim 55 \mathrm{mCi} / \mathrm{mmol}){ }^{1}\left({ }^{14} \mathrm{C}\right.$-leu $)$ and sodium $\left[\mathrm{C}^{14}\right]$ bicarbonate (sp act $\sim 50 \mathrm{mCi} / \mathrm{mmol}$ ) were purchased from Amersham (Amersham Corp., Buckinghamshire, UK). L- $\left[{ }^{15} \mathrm{~N}\right] \mathrm{leu}-$ cine $(>99 \% \text { mol percent enrichment, MPE })^{1}\left({ }^{15} \mathrm{~N}-\right.$ leu $)$ and L-[ring$\left.{ }^{2} \mathrm{H}\right]$ phenylalanine ( $\left.>99 \% \mathrm{MPE}\right)\left(\mathrm{D}_{5}\right.$-phe) were purchased from Tracer Technologies (Somerville, MA). All isotopes were proven to be sterile and pyrogen-free before use.

Experimental design. Six male healthy volunteers (age: 22-26 yr, body mass index: $22-25 \mathrm{~kg} / \mathrm{m}^{2}$ ) were admitted into our metabolic unit at 07:00 a.m. after the overnight fast. The protocol was explained in

1. Abbreviations used in this paper: A-V, arterio-venous; GCMS, gas chromatography mass spectrometry; HPLC, high performance liquid chromatography; KIC, $\alpha$-ketoisocaproic acid; MPE, mole percent enrichment; Ra, rate of appearance; Rd, rate of disappearance. 
detail to each subject, who signed a written consent to the study. In the absence of an ethical committee, the study was approved by the director of the department and it was performed under the recommendations of the radiation safety officer. Whole body radiation exposure resulting from the infusion of $\sim 100 \mu \mathrm{Ci}$ of the ${ }^{14} \mathrm{C}$ isotopes was estimated to be $\sim 100 \mathrm{mrad}(30)$.

Polyethylene catheters were placed percutaneously into the brachial artery and, in a retrograde fashion, into an ipsilateral deep forearm vein of the elbow, until the tip of catheter was no longer palpable under the skin. This vein drained predominantly blood from muscle tissue (31). An additional catheter was placed into an antecubital vein of the opposite arm and used for isotope infusions. At $-240 \mathrm{~min}$, primed continuous infusions of ${ }^{14} \mathrm{C}$-leu, of ${ }^{15} \mathrm{~N}$-leu, and of $\mathrm{D}_{5}$-phe were started by means of a calibrated pump (Harvard Apparatus, South Natick, MA). The rates of isotope infusion were $\sim 6,125 \mathrm{dpm} /$ $\mathrm{kg} \cdot \min$ for the ${ }^{14} \mathrm{C}-\mathrm{leu}, \sim 0.14 \mu \mathrm{mol} / \mathrm{kg} \cdot \min$ for the ${ }^{15} \mathrm{~N}$-leu, and 0.05 $\mu \mathrm{mol} / \mathrm{kg} \cdot \min$ for the $\mathrm{D}_{5}$-phe. Isotope priming doses were equivalent to $\times 60$ the corresponding continuous infusion rate per min. The bicarbonate pool was primed with $3 \mu \mathrm{Ci}$ of $\left[{ }^{14} \mathrm{C}\right]$ bicarbonate. Venous plasma samples were taken every $60 \mathrm{~min}$ for $3 \mathrm{~h}$, i.e., until the -60 th min (data not shown), to assess the achievement of steady state in isotope and substrate concentrations. Steady state was defined as absence of a slope significantly different from 0 , as well as of changes in concentrations, specific activities and enrichments greater than $5 \%$
(Fig. 1). Thereafter, between -60 and $0 \mathrm{~min}$, four samples of arterial and deep-venous blood, as well as of expired ${ }^{14} \mathrm{CO}_{2}$, were collected at 20-min intervals for baseline measurements. During sample collection, blood flow to the hand was excluded with a pediatric sphygmomanometer placed around the wrist and inflated above systolic pressure. Each arterial sample was collected starting few seconds after completion of the venous sample to avoid acute forearm hypoperfusion.

At $0 \mathrm{~min}$, the administration of a liquid mixed meal of defined composition (Nutrodrip Protein; Sandoz Nutrition, Wander Italia S.P.A, Milano, Italy) was started. The entire meal $(\sim 15 \mathrm{kcal} / \mathrm{kg}$ of body wt) was divided into isocaloric aliquots given every 20 min over $4 \mathrm{~h}$. Meal composition (in grams $/ 100 \mathrm{ml}$ ) was the following: carbohydrates 14.8 ; protein hydrolysate 6.6 ; lipids 4 . In addition, it contained minerals and vitamins. The proteins were derived from soy and casein. The lipids were constituted by $40 \%$ linoleic acid, by $6.5 \%$ MCT oil, the remainder by mono- and diglycerides. Thus, $\sim 49 \%$ of meal calories were represented by carbohydrates, $\sim 22 \%$ by proteins and $\sim 29 \%$ by lipids. Expired air, and arterial and deep-venous blood samples were again collected at 170, 190, 210, 230, and $250 \mathrm{~min}$, i.e., 10 min after administration of each meal aliquot. Steady state in all measured parameters were attained at least by $170 \mathrm{~min}$ after start of the meal (Fig. 1).

Analytical measurements. $10 \mathrm{ml}$ of blood was collected from each vessel into EDTA tubes and rapidly centrifuged at $+4^{\circ} \mathrm{C}$. The plasma
WHOLE BLOOD

LEUCINE, PHENYLALANINE AND KIC CONCENTRATIONS
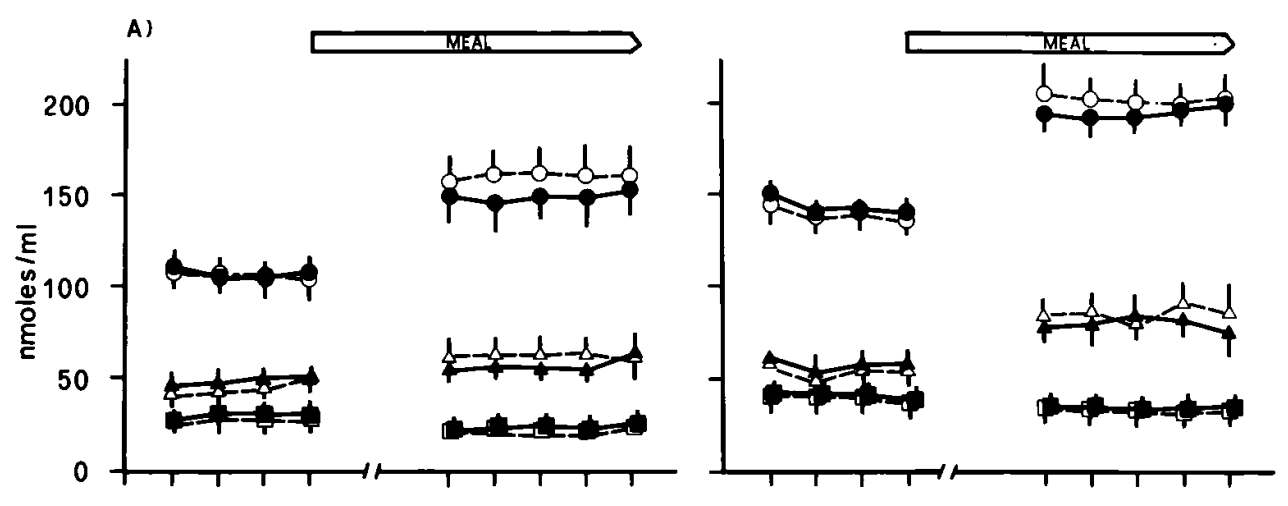

${ }^{14} \mathrm{C}$-LEUCINE , ${ }^{14} \mathrm{C}$-KIC AND ${ }^{14} \mathrm{C}$-BICARBONATE CONCENTRATIONS
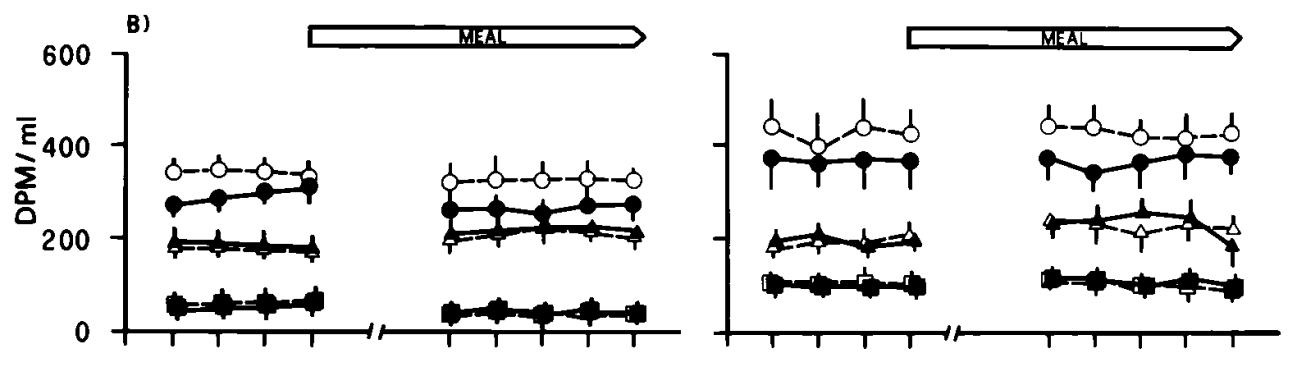

${ }^{15} \mathrm{~N}$-LEUCINE, $\mathrm{D}_{5}$-PHENYLALANINE CONCENTRATIONS
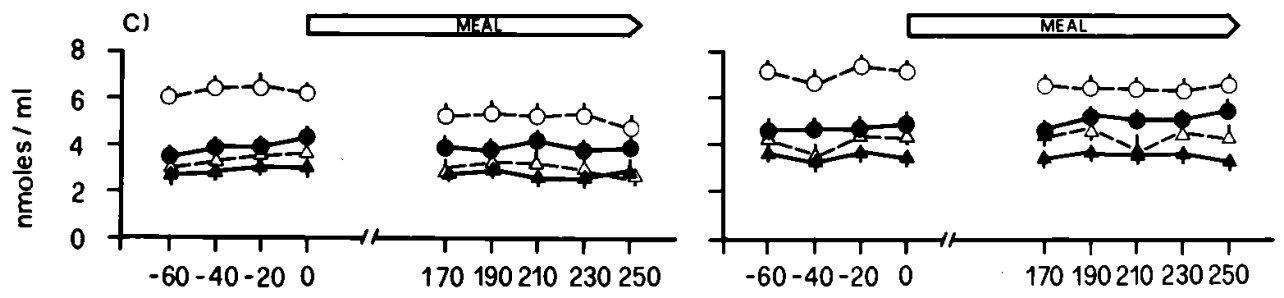

MINUTES
Figure 1. Substrate and isotope concentrations in the basal (from min $-60-0)$ and meal periods (from min 170-250). (Left panels) whole blood data. (Right panels) plasma data. Full symbols \& continued lines: arterial values. Empty symbols \& dotted lines: venous values. $(A)$ unlabeled leucine (circles), phenylalanine (triangles) and $\alpha$-ketoisocaproate (KIC) (squares) concentrations. (B) ${ }^{14} \mathrm{C}$-leucine (circles), $\left[{ }^{14} \mathrm{C}\right] \mathrm{bi}-$ carbonate (triangles) and ${ }^{14} \mathrm{C}-\mathrm{KIC}$ (squares) isotope concentrations. (C) ${ }^{15} \mathrm{~N}$-leucine (circles) and $\mathrm{D}_{5}$-phenylalanine (triangles) isotope concentrations. 
was then stored at $-20^{\circ} \mathrm{C}$ before assay. An additional $4 \mathrm{ml}$ of blood was collected into preweighed chilled tubes containing $2 \mathrm{ml}$ of $20 \%$ ( $\mathrm{vol} / \mathrm{vol})$ perchloric acid (PCA) as well as known amounts of the internal standards ketoleucine and ketocaproic acid, for whole blood analyses. The tubes were vigorously shaken and reweighed to determine accurately the amount of blood added. After centrifugation, the supernatant was stored at $-20^{\circ} \mathrm{C}$ until assay.

Plasma leucine and KIC concentrations and specific activity (32), as well as plasma phenylalanine concentrations (33) were determined by HPLC as referenced. Whole blood concentrations and specific activities were determined using the above-referenced HPLC methods, after corrections for dilution of blood with the PCA. Plasma and whole blood samples were processed in the same day and in the same assay. Leucine and phenylalanine concentrations in red blood cells were calculated from whole blood and plasma data, as well as from the hematocrit value, according to Hagenfeldt et al. (34).

Molar ratios of ${ }^{15} \mathrm{~N}$-leucine and of $\mathrm{D}_{5}$-phenylalanine in both whole blood and plasma were determined by gas chromatography mass spectrometry (GCMS), as tert-butyl-dimethyl-sylil-derivatives and electron impact ionization (35). Isotope ratios (i.e., tracer/ tracee ratios) were converted into molar ratios using appropriate standard curves. The enrichment was expressed as tracer/(tracer+ tracee) ratio, therefore as MPE. Isotope concentrations were calculated by multiplying either specific activity or MPE times unlabeled substrate concentration.

Arterial and deep venous concentration of blood $\left[{ }^{14} \mathrm{C}\right]$ bicarbonate was measured by adding $\sim 2 \mathrm{ml}$ of whole blood, immediately after collection, into preweighed glass vials containing $2 \mathrm{ml}$ of $20 \%$ perchloric acid in the bottom, as well as indwelling inner plastic tubes containing $0.5 \mathrm{ml}$ of $0.5 \mathrm{M}$ hyamine. The system was air tight. The vials were reweighed after blood addition to measure accurately the amount of blood added, gently stirred, and incubated for $2 \mathrm{~h}$ at $37^{\circ} \mathrm{C}$ in a shaking bath, to develop the ${ }^{14} \mathrm{CO}_{2}$ which was trapped into the hyamine solution. The indwelling hyamine-containing vials were then removed and accurately cleaned outside. After addition of $3.5 \mathrm{ml}$ of a scintillation cocktail (Ionic Fluor; Packard Instrument Co, Meriden, $\mathrm{CT}$ ) these vials were vigorously shaken, allowed to equilibrate in the dark for $24 \mathrm{~h}$, and counted. Recovery of $\left[{ }^{14} \mathrm{C}\right]$ bicarbonate added to this system was $>95 \%$. No correction factor for forearm bicarbonate fixation was employed, since such a "fixation" does not apparently occur across a sampled limb, at least in dogs (36).

Plasma $\left[{ }^{14} \mathrm{C}\right]$ bicarbonate concentration was measured as described for whole blood with the following modifications. Immediately after withdrawal, an additional $4 \mathrm{ml}$ of blood was mixed with $100 \mu \mathrm{l}$ of $6 \%$ EDTA. Then, $\sim 1 \mathrm{ml}$ of vaseline oil was gently layered on top to prevent gas exchange between blood and ambient air. The tubes were centrifuged within 10 to $20 \mathrm{~min}$ from collection. $2 \mathrm{ml}$ of plasma was then aspirated and immediately added to the $\left[{ }^{14} \mathrm{C}\right]$ bicarbonate trapping system, as described above. Plasma flow was determined with a dye dilution method using Indocyanine Green (Vert d'Indocyanine; SERB, Paris, France), as described in detail elsewhere (17). Briefly, the dye was dissolved with $0.9 \%$ saline containing $5 \%$ albumin. This solution was infused directly into the arterial catheter by means of a calibrated pump. Blood flow to the hand was excluded with a pediatric sphygmomanometer placed around the wrist and gently inflated above systolic pressure. After $\sim 5 \mathrm{~min}$ of dye infusion, a deep venous sample was collected very slowly, in order to avoid flow perturbation. Concentration of the dye in the infusate as well as in the serum samples, after proper dilution, were determined spectrophotometrically at $805 \mathrm{~nm}$. At least two determinations for each period (i.e., in the basal state and following the meal) were performed, and the resulting values were averaged. Dye recirculation was quantitated in samples taken from a vein of the opposite arm, and found to be negligible $(<5 \%)$. Whole blood flow was calculated by dividing plasma flow over [1-hematocrit]. Forearm mass (approximate forearm volume) was measured by anthropometry by considering the forearm (without the hand) as a truncated cone.

The ${ }^{14} \mathrm{CO}_{2}$ in the expired air was determined as described previ- ously $(8,9)$. Bicarbonate fixation factors of 0.76 in the fasting state, and of 0.91 in the fed state, were employed (37). Insulin (38) and glucagon (39) were determined by radioimmunoassay. Plasma glucose was measured using a Glucose Analyzer 2 (Beckman Instruments Inc, Fullerton, CA). Plasma arterial amino acid concentrations were determined by ion exchange chromatography using an Amino Acid Analyzer (Beckman Instruments).

Calculations. The four steady state basal values (i.e., between -60 and $0 \mathrm{~min}$ ), as well as those taken in the last $60 \mathrm{~min}$ of meal administration (i.e., between 190 and $250 \mathrm{~min}$ ) were averaged. Basal and after meal amino acid kinetics were determined on these mean data.

Forearm leucine and KIC kinetics, both in plasma and in whole blood, were calculated using a six-compartment forearm leucine model (27). Model assumptions and equations are reported in the Appendix, and they have been discussed in detail (27). Briefly, one feature of this model is the use of venous KIC specific activity to calculate all intracellular leucine kinetic rates. Another is the use of two different tracers of leucine simultaneously $\left({ }^{14} \mathrm{C}\right.$ and ${ }^{15} \mathrm{~N}$-leucine), to calculate leucine exchange between extracellular (either plasma or whole blood) and intracellular spaces, as well as leucine-KIC interconversions. Forearm phenylalanine kinetic was calculated by employing the classic A-V model of Gelfand and Barrett to both plasma and whole blood data (15).

Forearm amino acid balance was expressed as the difference between amino acid incorporation into protein synthesis (i.e., rate of disappearance, $\mathrm{Rd}$, for phenylalanine, and $\mathrm{F} 6$ for leucine) and amino acid release from protein degradation (i.e., rate of appearance, $\mathrm{Ra}$, for phenylalanine, and F5 for leucine).

Whole body leucine and phenylalanine $\mathrm{Ra}$, in both plasma and whole blood, were calculated using conventional formulas $(40,41)$. The leucine data were expressed using both the primary and the reciprocal pool model (40). Leucine oxidation was calculated by dividing the rate of ${ }^{14} \mathrm{CO}_{2}$ expiration (in $\mathrm{dpm} / \mathrm{kg} \cdot \mathrm{min}$ ) over either leucine specific activity (primary pool model) or KIC specific activity (reciprocal pool model). The rate of leucine disposal into protein synthesis was calculated by subtracting leucine oxidation from $\mathrm{Ra}$ (equal to $\mathrm{Rd}$ at steady state). Data extrapolation from the forearm to estimated total skeletal muscle was performed by assuming that $\sim 64 \%$ of forearm volume is represented by muscle (42), and that total muscle represents $\sim 40 \%$ of body weight (43). The rates extrapolated from forearm to total muscle were compared to whole body leucine kinetics calculated with the reciprocal pool model (40).

Statistical analysis. The statistical analysis was performed using two tailed paired tests (either the Student's $t$ test, or the Wilcoxon test) to compare two sets of data within the same group of subjects, such as meal vs basal periods, arterial vs venous values, plasma vs whole blood measurements, or selected kinetics rates (i.e., F7 vs F8, F5 vs F6, Ra vs Rd, F2 vs F3). A $P$ value less than 0.05 was considered statistically significant. All data were expressed as mean \pm SEM.

\section{Results}

\section{Glucose, hormone and amino acid concentrations, forearm} flow, and glucose disposal

Glucose concentrations in arterial plasma increased slightly but significantly with the meal $(P<0.001)$, from $83 \pm 7$ to $102 \pm 11 \mathrm{mg} / \mathrm{dl}$. Whole blood and plasma flow increased by $\sim 30 \%(P<0.05)$ (Table I). Net forearm glucose disposal increased by approximately sixfold $(P<0.001)$ from $8.9 \pm 2.4$ $\mathrm{mg} / \mathrm{min} \cdot 100 \mathrm{ml}$ of forearm in the basal state, to $52.5 \pm 14.4 \mathrm{mg} /$ min $100 \mathrm{ml}$ during the meal. Arterial insulin increased $(P<$ 0.01 ) from $79 \pm 14$ to $539 \pm 101 \mathrm{pmol} /$ liter, while glucagon (measured in four subjects) increased in two subjects while it decreased in the other two, resulting in no change (before meal: $88 \pm 12 \mathrm{ng} /$ liter; following the meal: $92 \pm 18 \mathrm{ng} /$ liter). 
Table I. Whole Blood and Plasma Forearm Flow (Expressed as $\mathrm{ml} / \mathrm{min} \cdot 100 \mathrm{ml}$ of Forearm) in the Basal, Postabsorptive State and during the Meal

\begin{tabular}{llc}
\hline & Basal & Meal \\
\hline Whole blood flow & $40.8 \pm 3.3$ & $53.9 \pm 5.9^{*}$ \\
Plasma flow & $23.9 \pm 1.8^{\ddagger}$ & $31.5 \pm 2.9^{\ddagger}$
\end{tabular}

${ }^{*} P<0.05$ vs basal: ${ }^{\ddagger} P<0.01$ vs whole blood.

Arterial plasma concentrations of most amino acids increased to a variable extent as expected following a mixed meal (Table II). Only taurine concentrations decreased. The largest increments were observed for the branched chain amino acids, as classically described (44).

Substrate and isotope concentrations of phenylalanine, leucine, KIC, and of $\left[{ }^{14} C\right]$ bicarbonate (Tables III and IV). Substrate and isotope amino acid as well as KIC concentrations tended to be lower in whole blood than in plasma, albeit with variable statistical significance (Tables III and IV). These differences were most marked for KIC concentration. In contrast, whole blood specific activities and enrichments were not statistically different from those measured in plasma (Tables III and IV). In the fasting state, leucine and phenylalanine concentrations in venous plasma, as well as phenylalanine concentration in venous blood, were significantly greater than the corresponding arterial values, indicating net amino acid release (Tables III and IV). Deep-venous KIC concentrations were slightly but insignificantly greater than in the artery, both in whole blood and plasma (Table IV). The calculated leucine concentration in arterial red blood cells $(75 \pm 15 \mu \mathrm{mol} /$ liter $)$ was not different from

Table II. Arterial Plasma Amino Acid Concentrations ( $\mu$ mol/liter)

\begin{tabular}{lcc}
\hline & Basal & Meal \\
\hline Citrulline & $26 \pm 1$ & $29 \pm 1$ \\
Valine & $211 \pm 15$ & $339 \pm 36^{*}$ \\
Methionine & $14 \pm 1$ & $30 \pm 2^{*}$ \\
Isoleucine & $53 \pm 4$ & $112 \pm 14^{*}$ \\
Tyrosine & $47 \pm 4$ & $91 \pm 8^{*}$ \\
Ornithine & $47 \pm 3$ & $73 \pm 4^{*}$ \\
Lysine & $144 \pm 7$ & $260 \pm 24^{*}$ \\
Histidine & $60 \pm 4$ & $81 \pm 4^{*}$ \\
Arginine & $73 \pm 3$ & $110 \pm 12$ \\
Taurine & $48 \pm 3$ & $39 \pm 2^{*}$ \\
Aspartate & $16 \pm 3$ & $20 \pm 3^{*}$ \\
Threonine & $107 \pm 9$ & $149 \pm 8^{*}$ \\
Serine & $109 \pm 7$ & $133 \pm 5$ \\
Asparagine & $25 \pm 2$ & $45 \pm 2^{*}$ \\
Glutamate & $152 \pm 27$ & $152 \pm 22$ \\
Glutamine & $366 \pm 39$ & $405 \pm 25$ \\
Proline & $215 \pm 34$ & $367 \pm 23^{*}$ \\
Glycine & $191 \pm 16$ & $185 \pm 6$ \\
Alanine & $240 \pm 34$ & $272 \pm 23^{*}$
\end{tabular}

Leucine and phenylalanine concentrations are reported on Tables III and IV. $* P<0.01$ vs baseline.
Table III. Phenylalanine (Phe) Concentration ( $\mu$ mol/liter) (Conc), Phe Mol Percent Enrichment (MPE, $\times 100)$, in Arterial (art) and in Forearm Venous (ven) Whole Blood and Plasma, during the Basal and the Meal Periods

\begin{tabular}{|c|c|c|c|c|}
\hline & \multicolumn{2}{|c|}{ Whole blood } & \multicolumn{2}{|c|}{ Plasma } \\
\hline & Basal & Meal & Basal & Meal \\
\hline Conc $_{\text {art }}$ & $41.4 \pm 3.6$ & $59.2 \pm 4.9^{\ddagger}$ & $53.2 \pm 5.2^{\S}$ & $84.8 \pm 9.0^{\ddagger \S}$ \\
\hline Conc $_{\mathrm{ven}}$ & $46.2 \pm 3.8 * *$ & $54.7 \pm 4.1^{\text {II }}$ & $56.6 \pm 5.9^{\|\pi\|}$ & $80.3 \pm 8.4^{\ddagger * * * \|}$ \\
\hline $\mathrm{D}_{5}-\mathrm{MPE}_{\mathrm{art}}$ & $7.57 \pm 0.641$ & $4.98 \pm 0.45^{\ddagger}$ & $7.80 \pm 0.56$ & $5.03 \pm 0.33^{\ddagger}$ \\
\hline $\mathrm{D}_{5}-\mathrm{MPE}_{\mathrm{ven}}$ & $6.17 \pm 0.64 * *$ & $4.63 \pm 0.49^{\ddagger \pi}$ & $6.23 \pm 0.48^{* *}$ & $4.76 \pm 0.28 * *$ \\
\hline $\mathrm{D}_{5}$-nmol $\mathrm{nart}_{\mathrm{a}}$ & $3.23 \pm 0.49$ & $2.98 \pm 0.43^{*}$ & $4.15 \pm 0.42^{\S}$ & $4.18 \pm 0.36^{\S}$ \\
\hline $\mathrm{D}_{5}-\mathrm{nmol}_{\mathrm{ven}}$ & $2.88 \pm 0.47 * *$ & $2.55 \pm 0.35^{* *}$ & $3.62 \pm 0.44 * * \S$ & $3.63 \pm 0.40 * *$ \\
\hline
\end{tabular}

${ }^{*} P<0.01 ;{ }^{\ddagger} P<0.01$ meal vs basal values; ${ }^{\S} P<0.05 ; \| P<0.01$ plasma vs whole blood values; ${ }^{\text {I }} P<0.05 ; * * P<0.01$ vein vs artery.

that in venous cells $(73 \pm 14 \mu \mathrm{mol} / \mathrm{liter})$; however, phenylalanine concentration in arterial blood cells $(23 \pm 8 \mu \mathrm{mol} / \mathrm{liter})$ was lower $(P=0.032)$ than that in venous cells $(30 \pm 8 \mu \mathrm{mol} / \mathrm{liter})$.

Specific activities and enrichments in the artery were greater than in the vein, indicating isotope dilution by unlabeled substrate(s) released by forearm tissues. In contrast, isotope concentrations were greater in the artery than in the vein, indicating simultaneous substrate uptake (Tables III-IV).

Labeled bicarbonate concentrations, both in whole blood and in plasma, were $2-5 \%$ greater in vein than in artery, consistently with a net production of ${ }^{14} \mathrm{CO}_{2}$ from forearm leucine oxidation (Table IV). Plasma $\left[{ }^{14} \mathrm{C}\right]$ bicarbonate concentrations were significantly greater than in whole blood (Table IV) both in arterial and in venous samples. The postabsorptive rate of ${ }^{14} \mathrm{CO}_{2}$ whole body production, at steady state, was $1601 \pm 169$ $\mathrm{dpm} / \mathrm{kg} \cdot \min$.

Following the meal, arterial phenylalanine and leucine concentrations increased (Tables III and IV), while arterial specific activities and enrichments decreased, indicating entry of unlabeled amino acids into both plasma and whole blood extracellular pools. In contrast, KIC concentrations decreased, this change being significant only in arterial plasma (Table IV). The forearm switched to net amino acid uptake, as calculated from both whole blood and plasma data (Tables III and IV). The calculated leucine concentration in arterial red blood cells $(112 \pm 32 \mu \mathrm{mol} /$ liter $)$ became significantly greater $(P<$ $0.01)$ than that in venous cells $(86 \pm 30 \mu \mathrm{mol} /$ liter $)$, thus resulting in a positive A-V leucine balance (by $26 \pm 4 \mu \mathrm{mol} /$ liter). This A-V difference was significantly greater $(P=0.005)$ than that observed in the postabsorptive state $(2 \pm 2 \mu \mathrm{mol} / \mathrm{liter})$. Phenylalanine concentration in arterial red blood cells $(20 \pm 11$ $\mu \mathrm{mol} / \mathrm{liter})$ tended to be greater than that in the vein $(16 \pm 9$ $\mu \mathrm{mol} / \mathrm{liter}$ ), however this difference was not significant. Also the net $\mathrm{A}-\mathrm{V}$ difference of phenylalanine concentration in red blood cell rose $(P=0.063)$ from $-7 \pm 3 \mu \mathrm{mol} /$ liter in the postabsorptive state, to $4 \pm 5 \mu \mathrm{mol} /$ liter following the meal.

The A-V differences of leucine and phenylalanine specific activities and enrichments decreased following the meal, suggesting a diminished release of unlabeled amino acids into the vein from forearm tissues.

Concentrations of $\left[{ }^{14} \mathrm{C}\right]$ bicarbonate tended to increase, both in whole blood and in plasma, although not significantly, with the exception of the venous plasma values (Table IV). 
Table IV. Leucine (Leu) and $\alpha$-Ketoisocaproic Acid (KIC) Concentration ( $\mu$ mol/liter) (Conc), ${ }^{14} \mathrm{C}$ Leu and ${ }^{14} \mathrm{C}$-KIC Isotope Concentrations $(\mathrm{dpm} / \mathrm{ml})$ and ${ }^{14} \mathrm{C}$-specific Activity $(\mathrm{SA})(\mathrm{dpm} / \mathrm{nmol}),\left[{ }^{14} \mathrm{C}\right]$ Bicarbonate Concentration $(\mathrm{dpm} / \mathrm{ml})\left({ }^{14} \mathrm{C}\right.$-Bic), ${ }^{15} \mathrm{~N}$-Leu Mole Percent Enrichment $(\mathrm{MPE}, \times 100)$ and Concentration, $\left({ }^{15} \mathrm{~N}\right.$-nmol) in Arterial (art) and in Forearm Deep Venous (ven) Whole Blood and Plasma, in both the Basal and the Meal Periods

\begin{tabular}{|c|c|c|c|c|}
\hline & \multicolumn{2}{|c|}{ Whole blood } & \multicolumn{2}{|c|}{ Plasma } \\
\hline & Basal & Meal & Basal & Meal \\
\hline \multicolumn{5}{|l|}{ Leucine } \\
\hline Conc $_{\text {art }}$ & $114 \pm 6$ & $170 \pm 17^{\ddagger}$ & $139 \pm 3^{\text {qI }}$ & $208 \pm 10^{\ddagger \pi}$ \\
\hline Conc $_{\text {ven }}$ & $116 \pm 6$ & $149 \pm 16^{\text {蛘 }}$ & $144 \pm 3 * * \pi$ & $191 \pm 10^{\ddagger * * \pi}$ \\
\hline${ }^{14} \mathrm{C}-\mathrm{SA}_{\text {art }}$ & $3.05 \pm 0.07$ & $1.92 \pm 0.04^{\ddagger}$ & $3.09 \pm 0.19$ & $2.04 \pm 0.11^{\ddagger}$ \\
\hline${ }^{14} \mathrm{C}_{-} \mathrm{SA}_{\mathrm{ven}}$ & $2.55 \pm 0.10^{\text {辛 }}$ & $1.81 \pm 0.06^{\ddagger * *}$ & $2.55 \pm 0.24^{\text {韩 }}$ & $1.88 \pm 0.11^{\text {辣 }}$ \\
\hline${ }^{14} \mathrm{C}-\mathrm{DPMS}$ art & $344 \pm 15$ & $325 \pm 33$ & $431 \pm 28^{\|}$ & $426 \pm 36^{\pi}$ \\
\hline${ }^{14} \mathrm{C}-\mathrm{DPMS}$ ven & 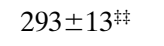 & $272 \pm 34 * *$ & $368 \pm 35^{\text {†⿰\# }}$ & $364 \pm 37^{+\neq \neq \|}$ \\
\hline${ }^{15} \mathrm{~N}-\mathrm{MPE}_{\mathrm{art}}$ & $5.48 \pm 0.43$ & $3.12 \pm 0.24^{\ddagger}$ & $5.21 \pm 0.38$ & $3.24 \pm 0.18^{\ddagger}$ \\
\hline${ }^{15} \mathrm{~N}-\mathrm{MPE}_{\mathrm{ven}}$ & $3.44 \pm 0.33^{\ddagger \ddagger}$ & $2.70 \pm 0.25 * *$ & $3.35 \pm 0.36^{\text {辛 }}$ & $2.71 \pm 0.19^{\ddagger \ddagger}$ \\
\hline${ }^{15} \mathrm{~N}-\mathrm{nmol}_{\text {art }}$ & $6.27 \pm 0.70$ & $5.13 \pm 0.39 *$ & $7.27 \pm 0.56^{\llbracket}$ & $6.65 \pm 0.21^{\|}$ \\
\hline${ }^{15} \mathrm{~N}-\mathrm{nmol}_{\mathrm{ven}}$ & $3.95 \pm 0.36^{\ddagger \ddagger}$ & $3.73 \pm 0.30 * *$ & $4.82 \pm 0.52^{\| \ddagger \ddagger}$ & $5.16 \pm 0.41^{\ddagger \neq ⿻ ~}$ \\
\hline \multicolumn{5}{|l|}{ KIC } \\
\hline Conc $_{\text {art }}$ & $26.1 \pm 2.5$ & $21.4 \pm 1.9$ & $40.4 \pm 3.3^{\mathbb{I I}}$ & $34.6 \pm 3.4 \ddagger \pi$ \\
\hline Conc $_{\text {ven }}$ & $28.6 \pm 3.1$ & $22.8 \pm 2.4 * *$ & $41.7 \pm 3.6^{\text {II }}$ & $36.5 \pm 4.2^{\mathbb{q}}$ \\
\hline${ }^{14} \mathrm{C}-\mathrm{SA}_{\mathrm{art}}$ & $2.44 \pm 0.26$ & $1.66 \pm 0.12^{\ddagger}$ & $2.55 \pm 0.21$ & $1.71 \pm 0.14^{\ddagger}$ \\
\hline${ }^{14} \mathrm{C}_{-} \mathrm{SA}_{\mathrm{ven}}$ & $2.24 \pm 0.28^{\text {辣 }}$ & $1.58 \pm 0.16^{\ddagger}$ & $2.33 \pm 0.25$ & $1.69 \pm 0.17^{\ddagger}$ \\
\hline${ }^{14} \mathrm{C}-\mathrm{DPMS}$ art & $62 \pm 6$ & $34 \pm 2^{\ddagger}$ & $103 \pm 9^{\pi}$ & $59 \pm 7^{\llbracket}$ \\
\hline${ }^{14} \mathrm{C}-\mathrm{DPMS}_{\mathrm{ven}}$ & $60 \pm 7$ & $35 \pm 3^{\ddagger}$ & $96 \pm 11^{* * * \pi}$ & $62 \pm 8^{\mathbb{T}}$ \\
\hline \multicolumn{5}{|c|}{${ }^{14} \mathrm{C}$-bicarbonate } \\
\hline${ }^{14} \mathrm{C}-\mathrm{Bic}_{\mathrm{art}}$ & $170 \pm 17$ & $208 \pm 16$ & $195 \pm 23 \|$ & $226 \pm 26$ \\
\hline${ }^{14} \mathrm{C}-\mathrm{Bic}_{\mathrm{ven}}$ & $178 \pm 17^{\text {辣 }}$ & $220 \pm 15^{*}$ *蚌 & $203 \pm 25^{\| * *}$ & $238 \pm 25$ \\
\hline
\end{tabular}

${ }^{*} P<0.05 ;{ }^{\ddagger} P<0.01$ meal vs basal values; ${ }^{\|} P<0.05 ;{ }^{\mathbb{P}} P<0.01$ plasma vs whole blood values; ${ }^{* *} P<0.05 ;{ }^{*} P<0.01$ vein vs artery.

Whole body ${ }^{14} \mathrm{CO}_{2}$ production at steady state increased $(P<$ 0.001 ) by $\sim 40 \%$ after the meal, to $2,229 \pm 172 \mathrm{dpm} / \mathrm{kg} \cdot \mathrm{min}$.

\section{Forearm phenylalanine and leucine kinetics}

Fasting state. Forearm phenylalanine $\mathrm{Ra}$ exceeded $\mathrm{Rd}$ when measured both from whole blood and plasma samples (Table V). Similarly, leucine release from forearm protein degradation (F5) exceeded its utilization for protein synthesis (F6) both in plasma and in whole blood samples (Table VI). Leucine deamination to KIC (F7) was greater than KIC reamination to leucine (F8), indicating net conversion of leucine into KIC (Table VI). Leucine oxidation (F9) was significantly greater than zero $(P<0.01)$. All these data indicate that the forearm was in a negative amino acid, therefore protein balance, as shown also in Figs. 2 and 3.

The rate of leucine inflow (F2) into cell was greater than outflow from cell (F3) (Table VI), although this difference was significant $(P=0.012)$ only in plasma data. The fraction of leucine shunting from artery to vein without being metabolized (F12) was $\sim 65 \%$ of arterial leucine delivery. Forearm KIC uptake (F10) was not different from release (F11) either from whole blood or plasma data. Forearm amino acid kinetic rates calculated in whole blood were generally greater than in plasma (Tables V and VI). In particular, the rate of leucine in-

Table V. Forearm Phenylalanine (Phe) Arterial (art) Delivery, Uptake (Rd), Release (Ra) and Net Balance, in the Basal, Postabsorptive State and following the Meal, Measured either in Plasma or in the Whole Blood

\begin{tabular}{|c|c|c|c|c|}
\hline & \multicolumn{2}{|c|}{ Whole blood } & \multicolumn{2}{|c|}{ Plasma } \\
\hline & Basal & Meal & Basal & Meal \\
\hline \multicolumn{5}{|l|}{ Art Phe } \\
\hline Delivery & $170.1 \pm 29.1$ & $326.9 \pm 67.5^{\S}$ & $125.9 \pm 18.4^{\pi}$ & $259.4 \pm 30.6^{\S}$ \\
\hline Phe Rd & $15.3 \pm 2.8$ & $45.7 \pm 12.8^{*}$ & $18.5 \pm 4.4$ & $24.2 \pm 3.7 *$ \\
\hline Phe Ra & $33.1 \pm 2.5^{* *}$ & $16.9 \pm 4.9^{\ddagger * *}$ & $25.4 \pm 2.6 * * \pi$ & $19.8 \pm 3.2^{\ddagger * *}$ \\
\hline Net Balance & $-17.8 \pm 1.4$ & $+28.7 \pm 13.7^{\ddagger}$ & $-8.4 \pm 3.2$ & $+4.4 \pm 1.4^{\mathbb{4} \S}$ \\
\hline
\end{tabular}

${ }^{*} P<0.01 ;{ }^{\ddagger} P<0.03 ;{ }^{\S} P<0.01$ meal vs basal values; ${ }^{\mathbb{T}} P<0.025$ plasma vs whole-blood values; $* * P<0.05$ or less vs Rd; all data are expressed as $\mathrm{nmol} / \mathrm{min} \cdot 100 \mathrm{ml}$ of forearm. 


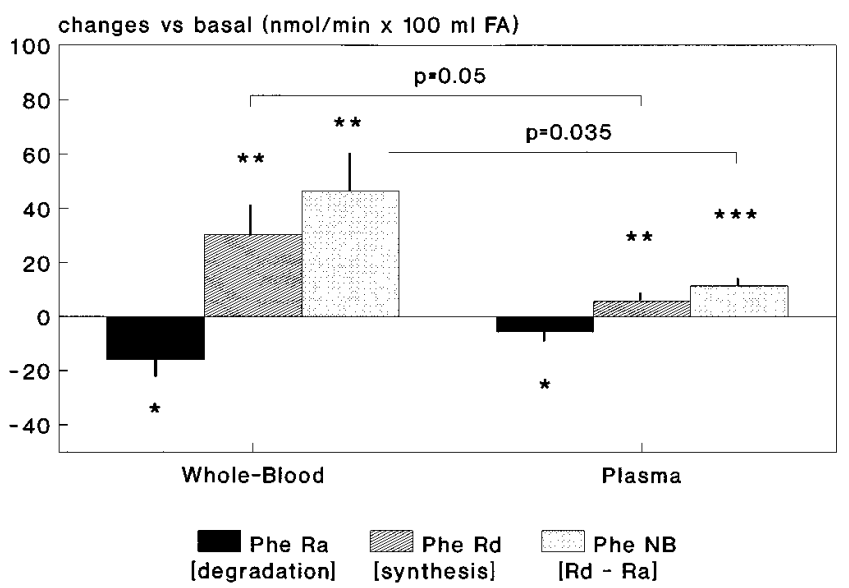

Figure 2. Changes vs baseline (expressed as $\mathrm{nmol} / \mathrm{min} \times 100 \mathrm{ml}$ of forearm [FA]) of phenylalanine (Phe) release from protein degradation $(\mathrm{Ra})$, disposal into protein synthesis $(\mathrm{Rd})$ and net balance $(\mathrm{NB})$ [Rd-Ra] following the meal. (Left panels) whole blood data. (Right panels) plasma data. Level of significant changes baseline: ${ }^{*} P<0.05$; $* * P<0.03$;*** $P<0.01$.

flow (F2) into cell, outflow from cell (F3), leucine deamination to $\mathrm{KIC}(\mathrm{F} 7), \mathrm{KIC}$ reamination into leucine (F8), as well as net leucine deamination (i.e., F7 minus F8) $(22.4 \pm 4.9$ in blood vs $9.8 \pm 2.0 \mathrm{nmol} / \mathrm{min} \cdot 100 \mathrm{ml}$ of forearm in plasma, $P=0.05$ ) were significantly faster when determined in whole blood than in plasma (Table VI). Blood forearm leucine oxidation tended also to be greater $(P<0.07)$ than when determined from plasma samples (Table VI). However, in the fasting state the net kinetic balance of these two essential amino acids, calculated as difference between amino acid utilization for protein synthesis minus release from protein degradation (see Methods), was not statistically different whether calculated in whole

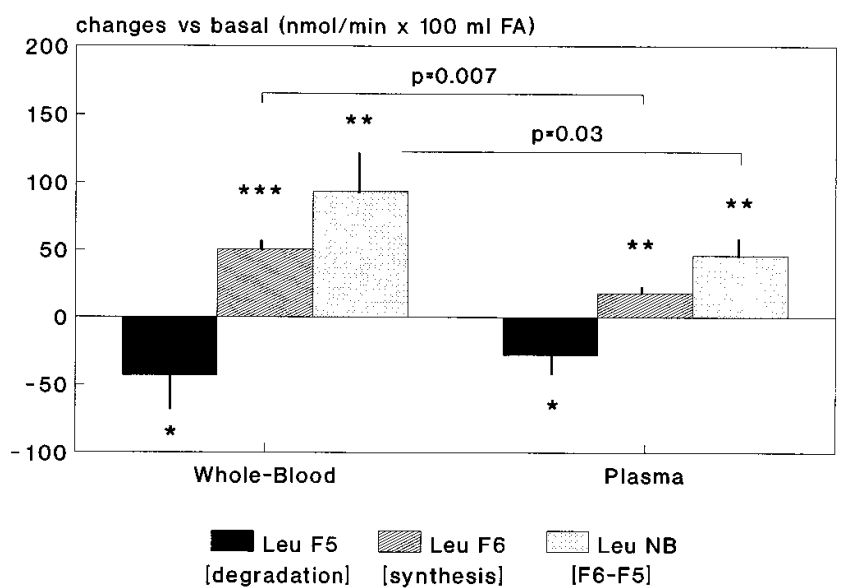

Figure 3. Changes vs baseline (expressed as nmol/min $100 \mathrm{ml}$ of forearm [FA]) of leucine (Leu) release from protein degradation (F5), disposal into protein synthesis (F6) and net balance (NB) (F6-F5) following the meal. (Left panels) Whole blood data. (Right panels)

Plasma data. Level of significant changes baseline: $* P<0.05 ; * * P<$ $0.03 ; * * * P<0.002$.

blood or in plasma (Tables V and VI). Interestingly, net forearm balance of phenylalanine was $\sim 50-70 \%$ lower than that of leucine, in good agreement with the relative abundance of these two essential amino acids in average tissue proteins (12).

Postprandial state. After the meal, the rate of arterial delivery of both phenylalanine and leucine to forearm (i.e., the product of arterial concentrations times flow) nearly doubled (Tables V and VI).

Forearm phenylalanine $\mathrm{Rd}$ increased by approximately threefold in whole blood $(P=0.046)$, and by $\sim 40 \%$ in plasma $(P=0.038)$ (Fig. 2 and Table V). Forearm phenylalanine Ra decreased by $\sim 50 \%$ in whole blood $(P=0.03)$ and by $\sim 20 \%$

Table VI. Forearm Leucine (Leu) and KIC Kinetics (nmol/min $100 \mathrm{ml}$ of Forearm), Estimated with the Six Compartment A-V Model, in the Basal, Postabsorptive State and following the Meal, as Measured either in Plasma or in the Whole Blood. (Art: Arterial)

\begin{tabular}{|c|c|c|c|c|}
\hline & \multicolumn{2}{|c|}{ Whole Blood } & \multicolumn{2}{|c|}{ Plasma } \\
\hline & Basal & Meal & Basal & Meal \\
\hline Art Leu delivery $(F 1)$ & $463 \pm 74$ & $907 \pm 179^{\S}$ & $325 \pm 35^{\text {辛 }}$ & $637 \pm 78^{\S \pi}$ \\
\hline Leu inflow from Art to Cell (F2) & $174 \pm 42$ & $221 \pm 54 *$ & $111 \pm 21^{\text {辛 }}$ & $144 \pm 32^{\ddagger}$ \\
\hline Leu outflow from Cell to Vein $(F 3)$ & $179 \pm 41$ & $111 \pm 33^{\S}$ & $123 \pm 22^{\ddagger \ddagger}$ & $92 \pm 21 * *$ \\
\hline Leu release into Vein $(F 4)$ & $468 \pm 73$ & $796 \pm 158^{\S}$ & $337 \pm 37^{\ddagger \ddagger}$ & $585 \pm 73 * * \S$ \\
\hline Leu release from Protein into Cell (F5) & $128 \pm 32$ & $85 \pm 28 *$ & $90 \pm 19$ & $62 \pm 17 *$ \\
\hline Leu uptake from Cell into Protein $(F 6)$ & $100 \pm 30^{\S \S}$ & $150 \pm 30^{\S \S \S}$ & $68 \pm 19^{\S \S}$ & $86 \pm 17 \div$ \\
\hline Leu conversion to $\mathrm{KIC}(F 7)$ & $150 \pm 42$ & $128 \pm 43$ & $82 \pm 15^{\text {辛 }}$ & $81 \pm 21^{9|\|| \mid}$ \\
\hline KIC conversion to Leu $(F 8)$ & $128 \pm 39|| \mid$ & $83 \pm 42^{\S\|\| !}$ & $72 \pm 14^{\ddagger \ddagger 1 \| 1}$ & $53 \pm 21^{\text {辛\|\|I }}$ \\
\hline Leu Oxidation $(F 9)$ & $13 \pm 3$ & $38 \pm 9 *$ & $7 \pm 1^{\|}$ & $23 \pm 6^{*} \|$ \\
\hline Art KIC delivery $(F 10)$ & $105 \pm 17$ & $114 \pm 21$ & $94 \pm 12$ & $110 \pm 21$ \\
\hline KIC release into Vein $(F 11)$ & $114 \pm 119$ & $121 \pm 22$ & $97 \pm 12$ & $115 \pm 21$ \\
\hline $\begin{array}{l}\text { Leu released from Art to Vein } \\
\text { without being metabolized (F12) }\end{array}$ & $289 \pm 38$ & $686 \pm 139^{\S}$ & $214 \pm 26^{\ddagger \ddagger}$ & $493 \pm 70^{\S \|}$ \\
\hline Net Balance $(F 6-F 5)$ & $-28 \pm 5$ & $+65 \pm 29$ & $-22 \pm 2$ & $+24 \pm 14^{\ddagger}$ \\
\hline
\end{tabular}

${ }^{*} P<0.05 ;{ }^{\ddagger} P<0.025 ;{ }^{\S} P<0.01$ meal vs basal values; ${ }^{\|} P<0.07 ;{ }^{\Uparrow} P<0.05 ; * * P<0.025 ;{ }^{\ddagger} P<0.01$ plasma vs whole blood values; ${ }^{\S \S} P<0.05$ or less vs F5; $1 \mathrm{II} P<0.05$ or less vs F7. 


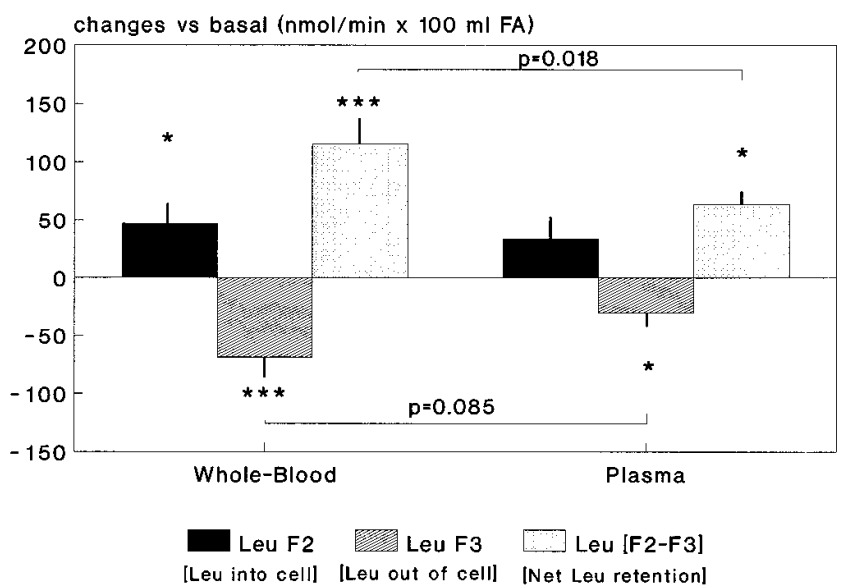

Figure 4. Changes vs baseline (expressed as $\mathrm{nmol} / \mathrm{min} 100 \mathrm{ml}$ of forearm [FA]) of leucine inflow into cell (F2), outflow from cell (F3), and net leucine retention by cell (F2-F3) following the meal. (Left panels) Whole blood data. (Right panels) Plasma data. Level of significant changes vs baseline: $* P<0.05 ; * * * P<0.01$.

in plasma $(P=0.028)$ (Fig. 2 and Table V). Net phenylalanine balance became positive, increasing by $+46.6 \pm 14 \mathrm{nmol} / \mathrm{min}$. $100 \mathrm{ml}$ of forearm in the whole blood $(P=0.029 \mathrm{vs} \mathrm{basal})$, and by $+11.4 \pm 2.9 \mathrm{nmol} / \mathrm{min} \cdot 100 \mathrm{ml}$ of forearm in plasma $(P=$ 0.011 vs basal) (Fig. 2, Table V). However, the relative increments vs baseline of both phenylalanine $\mathrm{Rd}$ and net balance in whole blood were significantly greater than those measured in plasma (Fig. 2). Leucine incorporation into protein synthesis (F6) increased by $\sim 50 \%$ in whole blood $(P=0.0013)$ and by $\sim 26 \%$ in plasma $(P=0.027)$ (Fig. 3 and Table VI). Leucine release from protein breakdown (F5) decreased by $\sim 30 \%$ in either whole blood $(P<0.05)$ or plasma $(P<0.05)$ (Fig. 3 and Table VI). Net leucine balance became positive too, increasing by $+93.5 \pm 29.4 \mathrm{nmol} / \mathrm{min} \cdot 100 \mathrm{ml}$ of forearm in whole blood $(P=0.024 \mathrm{vs}$ basal $)$ and by $+45.8 \pm 15.2 \mathrm{nmol} / \mathrm{min} \cdot 100 \mathrm{ml}$ of forearm in plasma $(P=0.029$ vs basal) (Fig. 3, Table VI). However, the relative increments vs baseline of both leucine incorporation into protein synthesis (F6) and net balance measured in whole blood were significantly greater than those measured in plasma (Fig. 3).

Leucine oxidation (F9) increased by approximately threefold $(P<0.05)$ in both whole blood and plasma (Table VI). Oxidation rates tended to be greater in blood than in plasma $(P=0.06)$ (Table VI). Leucine deamination to KIC (F7) and KIC reamination to leucine $(\mathrm{F} 8)$ tended to decrease vs baseline, although this change was significant only for F8 measured in whole blood (Table VI). Net leucine deamination (i.e., F7 minus F8) increased in both whole blood $(+22.4 \pm 8.4 \mathrm{nmol} /$ $\mathrm{min} \cdot 100 \mathrm{ml}$ of forearm $)$ and in plasma $(+18.1 \pm 5.7)(P<0.05$ or less vs baseline). In absolute terms, F7 (Table VI) as well as net leucine deamination $(44.8 \pm 9.2$ vs $27.8 \pm 5.0 \mathrm{nmol} / \mathrm{min} \cdot 100$ $\mathrm{ml})$ remained significantly greater in whole blood than in plasma ( $P=0.05$ or less $)$.

The rate of leucine inflow into cell $(\mathrm{F} 2)$ increased by $\sim 30 \%$ with the meal, although this change was significant only in whole blood (Table VI, Fig. 4). Leucine outflow from cell (F3) decreased ( $P<0.05$ or less) by $\sim 25-40 \%$ in both whole blood and plasma. The net difference between leucine inflow and outflow (i.e., F2 minus F3), which indicates net leu- cine retention within cell, increased markedly with the meal (Fig. 4) $(P<0.05, P<0.006)$. The net intracellular leucine retention was significantly greater when measured in blood than in plasma (Fig. 4).

Both KIC uptake (F10) and release (F11) tended to increase after the meal, although not significantly, and were not different from each other (Table VI).

\section{Whole body amino acid kinetics (Table VII)}

After the meal, phenylalanine Ra increased by $\sim 60 \%(P<$ $0.01)$. Leucine Ra, calculated either with the primary or the reciprocal pool, increased by $\sim 50 \%(P<0.01)$. Leucine oxidation increased by $\sim 100 \%(P<0.001)$. Leucine nonoxidative disposal, reflecting its utilization into whole body protein synthesis, increased by $\sim 30 \%(P<0.01)$. Leucine nitrogen flux increased by $\sim 90 \%(P<0.01)$.

\section{Discussion}

In this study we have investigated the mechanisms of postprandial amino acid (i.e., protein) accretion in human skeletal muscle. To this aim, we employed the forearm A-V catheterization approach in combination with the infusion of isotopes of two essential amino acids, leucine and phenylalanine, as well as with extensive measurements of all the leucine metabolic products. We show for the first time that, during mixed meal ingestion, forearm (i.e., muscle) proteolysis was markedly inhibited while forearm protein synthesis was stimulated. Therefore, both mechanisms contributed to net forearm amino acid (and protein) accretion after a meal.

We have studied also the role of red blood cells and/or of

Table VII. Whole Body Leucine and Phenylalanine Kinetics (expressed in $\mu \mathrm{mol} / \mathrm{kg} \cdot \mathrm{min}$ )

\begin{tabular}{|c|c|c|c|c|}
\hline & \multicolumn{2}{|c|}{ Whole Blood } & \multicolumn{2}{|c|}{ Plasma } \\
\hline & Basal & Meal & Basal & Meal \\
\hline \multirow[t]{2}{*}{ Leu $\mathrm{Ra}_{\mathrm{pp}}$} & 1.90 & $3.01^{*}$ & 1.94 & $3.01 *$ \\
\hline & \pm 0.08 & \pm 0.14 & \pm 0.05 & \pm 0.14 \\
\hline \multirow[t]{2}{*}{ LeuOx $_{p p}$} & 0.50 & $1.09^{*}$ & 0.51 & $1.10 *$ \\
\hline & \pm 0.04 & \pm 0.06 & \pm 0.04 & \pm 0.06 \\
\hline \multirow[t]{2}{*}{$\mathrm{Leu} \rightarrow \mathrm{PS}_{\mathrm{pp}}$} & 1.41 & $1.92 *$ & 1.43 & $1.91 *$ \\
\hline & \pm 0.10 & \pm 0.14 & \pm 0.08 & \pm 0.14 \\
\hline \multirow[t]{2}{*}{ Leu $\mathrm{Ra}_{\mathrm{rp}}$} & 2.38 & $3.63 *$ & 2.38 & $3.63 *$ \\
\hline & \pm 0.12 & \pm 0.18 & \pm 0.12 & \pm 0.18 \\
\hline \multirow[t]{2}{*}{ Leu $O x_{\mathrm{rp}}$} & 0.62 & $1.31^{*}$ & 0.62 & $1.33 *$ \\
\hline & \pm 0.06 & \pm 0.06 & \pm 0.06 & \pm 0.07 \\
\hline \multirow[t]{2}{*}{$\mathrm{Leu} \rightarrow \mathrm{PS}_{\mathrm{rp}}$} & 1.75 & $2.32^{*}$ & 1.75 & $2.31 *$ \\
\hline & \pm 0.12 & \pm 0.18 & \pm 0.12 & \pm 0.17 \\
\hline \multirow[t]{2}{*}{ Leu-N Ra } & 2.72 & $5.16^{*}$ & 2.65 & $4.18^{*}$ \\
\hline & \pm 0.20 & \pm 0.77 & \pm 0.22 & \pm 0.47 \\
\hline \multirow[t]{2}{*}{ Phenylalanine $\mathrm{Ra}$} & 0.62 & $0.98 *$ & 0.60 & $0.96^{*}$ \\
\hline & \pm 0.05 & \pm 0.08 & \pm 0.05 & \pm 0.07 \\
\hline
\end{tabular}

${ }^{*} P<0.01$ vs basal. The leucine data have been calculated both with the primary (pp) and the reciprocal (rp) model (40). Ra: Rate of Appearance; Ox: Oxidation; Leu $\rightarrow$ PS: Leucine utilization for protein synthesis; Leu-N: Leucine-Nitrogen Ra (calculated with the ${ }^{15} \mathrm{~N}$-isotope). 
blood flow in the regulation of forearm protein turnover. Forearm protein synthesis was significantly more stimulated when whole blood rather than plasma measurements were employed (Figs. 2 and 3), whereas postprandial forearm proteolysis was suppressed almost to the same extent using either data. Consequently, the increment in postprandial net amino acid (i.e., protein) accretion, which results from the difference between protein synthesis and degradation, was approximately twofold greater (leucine data) and approximately fourfold greater (phenylalanine data) when whole blood rather than plasma measurements were employed. Therefore, another finding of our study is that red blood cells (and/or blood volume) are an important determinant of postprandial protein deposition in human muscle. Indeed, nearly all other leucine kinetic data were significantly faster in whole blood than in plasma (Table VI).

Previous studies performed using the arteriovenous catheterization technique had shown that amino acid balance across the human leg becomes positive after ingestion of a protein meal (44), suggesting net protein accretion. However, the underlying mechanisms could not be elucidated, because no isotope-dilution method was there employed. By using arterialized venous and deep venous plasma sampling, forearm protein degradation was unchanged whereas synthesis was stimulated in fed vs fasted normal volunteers $(25,45)$. More recently, muscle fractional protein synthesis was stimulated by the meal in one controlled study (6) but it was unchanged in another (14); muscle protein degradation was not determined. Our forearm catheterization data agree with one of these studies (6) as regards meal-induced acute stimulation of forearm protein synthesis. They agree also with previous findings obtained at the whole body level, as regards the simultaneous inhibition of endogenous proteolysis and the stimulation of protein synthesis after a mixed meal (3-11).

As concerns the possible physiological mechanisms, the postprandial inhibition of forearm protein degradation might have been mediated by hyperinsulinemia, by hyperaminoacidemia, or by other factors. Insulin was shown to inhibit either forearm or leg proteolysis in some studies $(15,16,18)$ but not in others $(17,19,46)$. These discrepancies could arise because the insulin inhibitory effect might become evident, provided that arterial amino acid concentrations are not concurrently decreased $(15,16,18)$, as it occurs after a mixed meal. The molecular mechanism(s) for the insulin effect are however still unclear, since insulin was shown to suppress mainly lysosomal proteolysis, which, in turn, is not the predominant pathway of protein degradation in muscle $(47,48)$. Hyperaminoacidemia was shown to inhibit muscle protein degradation in muscle, both in vitro $(47,48)$ and in vivo in man $(26)$, although a recent study in pigs did not confirm this finding (49). The possible mechanisms for amino acid-induced suppression of proteolysis are discussed in detail (48). They may involve inhibition either of macroautophagy of nonmyofibrillar proteins, or of breakdown of nonlysosomal myofibrillar proteins. The branched chain amino acid leucine may be important in the suppression of muscle proteolysis, either directly or through its transamination product, $\alpha$-ketoisocaproate [KIC] (48). Leucine (and other branched-chain amino acid) concentrations exhibited the largest increments after the meal (Table II). Interestingly, however, KIC concentrations did not increase (Table IV), consistently with other reports $(3,4,8,9,11)$. On the whole, it is likely that both insulin and amino acids cooperated in the mealinduced inhibition of forearm muscle proteolysis observed in our study. As regards a possible role of the (modest) postprandial hyperglycemia, no inhibitory effect by glucose on proteolysis could be demonstrated in controlled studies $(50,51)$.

The potential mechanism(s) for meal-induced stimulation of muscle protein synthesis could also involve hyperinsulinemia, hyperaminoacidemia, or other hormonal, metabolic, and hemodynamic factors. Although the majority of published studies failed to show a clear-cut effect of insulin to stimulate either whole body or muscle protein synthesis (15-19, 52-54), other reports showed instead a stimulation $(46,55)$. In contrast, insulin clearly enhanced muscle protein synthesis in vitro (47). The molecular basis for this insulin-stimulatory effect may involve hormone-induced changes in tissue RNA concentrations, as well as in polysome levels and/or ribosome subunits (47). Hyperaminoacidemia in turn directly stimulated muscle protein synthesis both in vitro (47) and in vivo (26), even in the absence of hyperinsulinemia (49). The mechanisms for the latter effect are still obscure, since the amino acyl-transfer RNAs appear to be already maximally charged at the fasting amino acids levels (56). Therefore, any of the other steps controlling protein synthesis might theoretically be involved (47). The maintenance of adequate intracellular amino acid concentrations might also be required to elicit a stimulatory effect by insulin on muscle protein synthesis (55). Taken together, these data suggest that meal stimulation of forearm protein synthesis was largely mediated by the physiologic, postprandial hyperaminoacidemia, being possibly enhanced by hyperinsulinemia.

Forearm glucose utilization was markedly increased after the meal, as expected (see Results). It cannot be excluded that increased glucose metabolism by forearm tissues, mainly by muscle, might have provided energy to sustain protein synthesis.

Other hormonal factors, such as IGF-1 or growth hormone, might also have been involved in the stimulation of protein synthesis. Both these growth factors have been shown to enhance whole body as well as forearm protein synthesis (4, 57-59). Furthermore, IGF-1 augmented the amino acid-induced stimulation of protein synthesis in the human forearm (59). Unfortunately, these hormones could not be measured in this study. On the other hand, meal ingestion should result in minor acute changes in either growth hormone or IGF-1 concentrations (60).

Another potentially important regulatory factor may be a hemodynamic one. Forearm blood flow was stimulated by $\sim 30 \%$ during the meal (Table I). Increased amino acid delivery to the forearm, due also to stimulation of perfusion, might have been responsible for the observed increase of protein synthesis. It has been recently suggested that the enhancement of muscle protein synthesis in the recovery phase after exercise might be mediated by increased blood flow (61). Although potentially important, in our study the increase of forearm blood flow $(+30 \%)$ was smaller than the observed increased of protein synthesis $(+50 \%)$, thus explaining only partially the latter effect.

No stimulation of leg blood flow was previously detected after ingestion of a protein meal (44), at variance with the present report. This discrepancy could theoretically be due to differences in composition of the meal (a mixed one in the present study, a protein-meal in the cited one), to the way of meal administration (a continuous vs a bolus pattern), to a possibly different response of the leg vs the forearm, or to other undetermined factors.

We have employed an established A-V model to interpret forearm phenylalanine kinetics $(15,21)$. In addition, we have 
used a novel compartmental leucine model (27), which allows to estimate more extensively intracellular forearm leucine kinetics, as well as leucine movement between the extracellular and the intracellular space(s). One assumption of this model is that venous KIC SA, used to calculate all the intracellular leucine kinetic rates, is a reflection of intramuscular leucine specific activity (27). A direct assay of intracellular leucine SA/ MPE by biopsy would be definitively preferable. Nevertheless, the choice of the less-invasive venous KIC SA assumption is supported by many recent studies, in which venous KIC enrichment (or specific activity) was found to depart only marginally (by $\sim 5-15 \%$ ) from either free intracellular leucine or leucyl t-RNA enrichments $(49,62-65)$. Such a difference might be even less marked following meal-induced hyperaminoacidemia, because of a sort of "flooding effect" induced by the ingested amino acids.

The difference between leucine inflow (F2) minus outflow (F3) (Table VI) into/out of cell, which indicates net intracellular leucine retention, became markedly positive after the meal (Fig. 4). Thus, net leucine retention resulted from both a reduction of leucine outflow and a stimulation of leucine inflow out/into cell (Fig. 4, Table VI). Taken together, these observations suggest that increased protein synthesis in skeletal muscle might have been mediated also by retention within cell of this essential amino acid (through inhibition of endogenous protein breakdown and/or suppression of outflow from cell), in addition to the increased amino acid inflow from the extracellular to intracellular spaces.

The bidirectional transmembrane leucine exchange was calculated from the net extraction of the ${ }^{15} \mathrm{~N}$-leucine isotope relative to that of $\left[{ }^{14} \mathrm{C}\right]$ leucine (27) (see also the Appendix). The former isotope was assumed not to recycle back as venous ${ }^{15} \mathrm{~N}$-leucine, at variance with the latter. However, some ${ }^{15} \mathrm{~N}$ ammonia, generated intracellularly through ${ }^{15} \mathrm{~N}$-leucine deamination, might theoretically have been reaminated with KIC and released as ${ }^{15} \mathrm{~N}$-leucine into the vein. Such a recycling might be even higher when the mono-labeled ${ }^{15} \mathrm{~N}$-leucine (like that employed in this study) is used, rather than the di-labeled $\mathrm{L}-\left[1-{ }^{13} \mathrm{C},{ }^{15} \mathrm{~N}\right]$ leucine used by others $(25,45,66)$. Nevertheless, KIC conversion into leucine was actually decreased following the meal (Table VI), suggesting a decrease also of ${ }^{15} \mathrm{~N}$-recycling. In addition, although leucine inflow (F2) and outflow (F3) might be underestimated by isotope recycling, as discussed in detail (27), the net difference between [F2-F3] would not be at all affected. The above considerations apply also to leucine and KIC interconversion rates (F7 and F8), as well as to the net difference between [F7-F8] (27). Most importantly, it must be pointed out that the key model parameters, i.e., F5 (leucine release from proteolysis), F6 (leucine incorporation into protein synthesis), and leucine oxidation (F9), are totally unaffected by any ${ }^{15} \mathrm{~N}$-isotope recycling (27).

At variance with leucine, no intracellular model of regional phenylalanine kinetics is at present available, with the exception of that employing the arteriovenous catheterization combined with leg muscle biopsy (46). In that study, intracellular free phenylalanine enrichment in muscle was found to be $\sim 80 \%$ that of the vein, and $\sim 60 \%$ that of the artery (46). The enrichment of phenylalanine t-RNA in swine skeletal muscle was $\sim 70 \%$ that of the vein, and $\sim 64 \%$ that of artery (63). It is possible that use of more refined forearm phenylalanine models would give different estimate(s) of protein degradation and synthesis, both under fasting and fed conditions, although the relative changes occurring after a meal cannot be presently predicted.

As the relative abundance of leucine in skeletal muscle proteins is about 2.5 times that of phenylalanine (12), the leucine kinetic data should be proportionally higher than those of phenylalanine. In this study, despite the structural differences between the two amino acid models (as discussed above), the good qualitative as well as quantitative agreement between the phenylalanine (Table V) and the leucine data (Table VI) as regards forearm protein degradation and synthesis, strongly supports the validity of the study both in the fasted and the fed state.

We have extensively compared whole blood and plasmaderived measurements of forearm leucine and phenylalanine kinetics, since also red blood cells might take part in amino acid exchange between blood and tissue(s) $(28,29,34,67)$. In general, whole blood derived rates were faster than those measured in plasma (Tables V and VI), most likely because forearm whole blood flow was $\sim 40 \%$ higher than plasma flow. However, a specific role of red blood cells on forearm amino acid uptake cannot be excluded. In fact, suppression of forearm protein breakdown was of the same magnitude, whereas the postprandial stimulation of protein synthesis was approximately three- to fivefold greater when determined from blood than from plasma measurements (Tables V and VI; Figs. 2 and 3). Consequently, the net forearm kinetic balance of both amino acids was of similar magnitude from either plasma or whole blood data in the postabsorptive state, but clearly different following the meal.

In order to investigate further this issue, we have compared whole blood vs plasma fractional extraction (a measurement independent from flow) of labeled as well as unlabeled leucine and phenylalanine (data not shown). We did not observe significant differences between blood and plasma data. We have also estimated leucine and phenylalanine forearm exchange through erythrocytes, using the calculated A-V differences of amino acid concentrations in blood cells, which are accounted for by $>99 \%$ by the erythrocytes (34). Meal ingestion resulted in a net forearm uptake of leucine and, to a lesser and insignificant extent, also of phenylalanine, via blood cells (see Results). In kinetic terms, during the meal the forearm took up $\sim 60 \mu \mathrm{mol}$ of leucine $\left(\times 100 \mathrm{ml}\right.$ of forearm volume $\left.{ }^{-1} \times \mathrm{min}^{-1}\right)$ through cells. This figure accounted for $\sim 52 \%$ of total leucine uptake calculated from whole blood data (i.e., expressed by the difference between F4 and F1 in Table VI). Conversely, phenylalanine uptake through the cells was $\sim 16 \mu \mathrm{mol}(\times 100$ $\mathrm{ml}$ of forearm volume ${ }^{-1} \times \min ^{-1}$ ), which was $\sim 34 \%$ of total uptake from whole blood data (Table V). These figures do not depart much from the fraction of forearm whole blood flow contributed by the erythrocytes $(\sim 41 \%)$. Thus, it appears that red blood cells actively participate in the leucine and phenylalanine movements from the arterial blood to the forearm intracellular space, in agreement with previous findings (67). However, whether this is simply due to the greater mass of blood delivered to the forearm because of erythrocyte volume, or to a specific effect of blood cells themselves, cannot be established from our data. To this purpose, it would be interesting to compare forearm protein synthesis at comparable rates of blood flow but at different values of hematocrit.

In theory, forearm data may not strictly reflect only skeletal muscle metabolism, but also that of forearm skin $(68,69)$ and bone. However, the contributions by these latter tissues to 
forearm amino acid (and protein) kinetics are considered to be small, because about two-thirds of muscle mass are constituted by muscle (43), bone metabolism is likely to be slow, and skin may contribute no more than by $10 \%$ to limb protein turnover, at least in postabsorptive dogs (69).

We fed our volunteers a mixed liquid meal of defined and elementary composition, in order to avoid possible differences in absorption of more complex nutrients. Furthermore, we have chosen the continuous administration approach as others did $(3-6,9,11)$, in order to be able to perform all kinetic measurements at steady state. This pattern of meal administration is nevertheless employed in clinical nutrition. Although such a choice might be considered slightly unphysiological, it allowed to avoid uncertainties due to time-dependent changes in amino acid pool sizes and in other model parameters, which would follow a bolus meal. However, the systemic changes in amino acid and hormone concentrations, here observed, are those otherwise expected following a common mixed meal ingested as a bolus (8). Definitely, it would be interesting to compare the present findings with those occurring after a bolus mixed meal.

Postprandial forearm leucine utilization for protein synthesis increased by $\sim 50 \mathrm{nmol}$ (per $100 \mathrm{ml}$ of forearm $^{-1}$ per min $\mathrm{m}^{-1}$ ) (whole blood data). As leucine relative abundance in muscle proteins is $\sim 8 \%$, such an increase would correspond to $\sim 80$ $\mu \mathrm{g}$ of new protein synthesized per min per $100 \mathrm{ml}$ of forearm, or to $\sim 5 \mathrm{mg}$ per $\mathrm{h}$. Assuming that muscle represents $\sim 64 \%$ of forearm volume (43), and that total skeletal muscle is $\sim 40 \%$ of body weight (42), such an increment would imply synthesis of $\sim 2.2 \mathrm{~g}$ of skeletal muscle proteins per h. The relative increase of whole body nonoxidative leucine disposal (Table VII) was $\sim 0.57 \mu \mathrm{mol} / \mathrm{kg} \cdot \min$, i.e., $\sim 4 \mathrm{~g}$ of protein per hour. Thus, muscle would contribute by $\sim 50 \%$ to the observed postprandial increase of whole body protein synthesis.

In conclusion, our study shows that mixed meal ingestion in man enhances net forearm protein anabolism through both suppression of endogenous protein breakdown and stimulation of protein synthesis. Furthermore, it underlines an important role of blood flow (due to blood cells and/or to blood mass) in the regulation of postprandial forearm protein synthesis.

\section{Appendix}

\section{Six-compartment model}

Model assumptions and definitions. To describe leucine and KIC kinetics across the forearm the following models have been developed: $(a)$ a ${ }^{14} \mathrm{C}$-leucine, ${ }^{14} \mathrm{C}$-KIC "tracer" model; $(b)$ a ${ }^{15} \mathrm{~N}$-leucine "tracer" model; and $(c)$ a leucine and KIC "tracee" model. In Fig. 4, only the tracee model is reported. The ${ }^{14} \mathrm{C}$-leucine, ${ }^{14} \mathrm{C}$-KIC "tracer" model is the same as the tracee model, with the exception that no entry of labeled ${ }^{14} \mathrm{C}$-leucine into the intracellular leucine pool is assumed, and that the units are in $\mathrm{dpm} / \mathrm{min} \cdot 100 \mathrm{ml}$ of forearm (27). The ${ }^{15} \mathrm{~N}$-leucine tracer model is a three-compartment model with the following characteristics: no KIC compartment is present; reamination of KIC to leucine is considered to be negligible ( $\sim$ to zero); exit from the intracellular leucine compartment corresponds the combined loss of tracer to protein synthesis and deamination to $\mathrm{KIC}$; and no reentry of labeled ${ }^{15} \mathrm{~N}$-leucine into the intracellular leucine pool is assumed. Both tracer models are re- quired to solve the equations of the tracee model, which describes the physiologically relevant leucine and KIC parameters. The tracee leucine model is made of six compartments, three of leucine and three of KIC (Fig. 5). Units are in nmol/ $\mathrm{min} \cdot 100 \mathrm{ml}$ of forearm. For each substrate, one compartment is in the artery, one intracellular and one in the vein. The notations F1 and F4 indicate leucine tracee flux in the artery and in the vein, respectively. F2, F3 and F12 indicate leucine movements from artery to cell, from cell to vein and from artery directly to vein, respectively. F5 indicates release of leucine from protein into cell, i.e., it is an estimate of intracellular proteolysis. No tracer recycled from proteolysis is assumed to occur during the experiment. F6 indicates intracellular leucine incorporation into protein. $\mathrm{F} 7$ and F8 indicate leucine conversion to $\mathrm{KIC}$ as well as KIC to leucine, respectively. F9 indicates the irreversible loss of leucine into oxidation. Finally, F10 and F11 indicate KIC flux in the artery and in the vein, respectively. The principal assumptions of the model are the following: (a) The ${ }^{14} \mathrm{C}$-KIC SA measured in the venous blood is taken as representative of intracellular ${ }^{14} \mathrm{C}$-leucine as well as ${ }^{14} \mathrm{C}$-KIC SA. This assumption is based on recent human and animal data $(49,62-65)$. (b) The fraction of the ${ }^{15} \mathrm{~N}$-leucine tracer irreversibly disposed from plasma into the cell, calculated from the arterial-venous difference of ${ }^{15} \mathrm{~N}$-leucine isotope concentrations, is assumed to represent the "net metabolic leucine utilization." This figure is used to calculate leucine inward and outward movements across the cell membrane. These movements may underestimate leucine transport across the cell membrane, to the extent that ${ }^{15} \mathrm{~N}$-leucine tracer is either recycled back to the venous compartment without being metabolized, or it is derived, more unlikely, from KIC reamination. Therefore, we prefer to use the terms inflow and outflow instead that leucine inward and outward transport. Conversely, the fraction of ${ }^{15} \mathrm{~N}$ leucine tracer not taken up by the forearm is assumed to bypass intracellular metabolism and to be released directly into the vein. This figure will be applied to calculate the fraction of unlabeled leucine which escapes intracellular metabolism. (c) A single, well mixed intracellular leucine pool is also assumed,

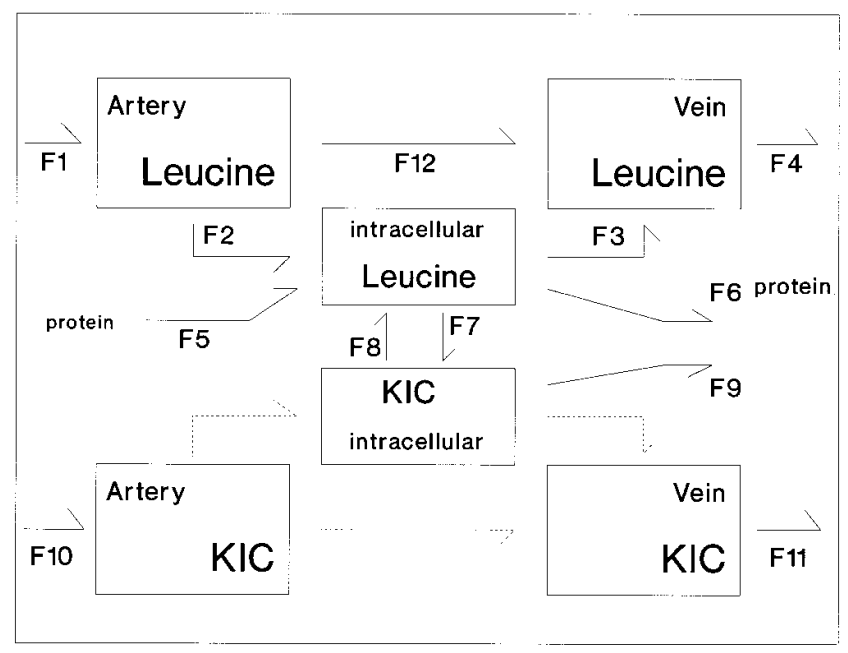

Figure 5. (Appendix). Tracee model of unlabeled leucine and KIC. The dotted arrows indicate rates that cannot be determined with the model here described. F5 corresponds to leucine coming from protein degradation, F6 to leucine disposal into protein synthesis. 
from and into which all entries and exits take place. The same assumptions are made as regards a homogeneous intracellular KIC pool. (d) No interstitial compartment is thus considered. The ${ }^{14} \mathrm{C}$-leucine, the ${ }^{14} \mathrm{C}$-KIC and the ${ }^{15} \mathrm{~N}$-leucine isotopes are assumed to enter their corresponding intracellular compartments at the arterial values; conversely, they are assumed to be released from their intracellular compartments at the measured deep venous values. (e) No release of tracer(s) recycled from protein breakdown into the intracellular leucine compartment is assumed to take place within the duration of the study. $(f)$ There is no independent production of KIC inside the cell except that deriving from leucine and from blood. $(g)$ Finally, we assume that the metabolic behavior of the ${ }^{14} \mathrm{C}$ tracer(s) are the same as that of unlabeled material.

In the following equations, Leu $(\mathrm{nmol} / \mathrm{ml}),{ }^{14} \mathrm{C}-\mathrm{Leu}(\mathrm{dpm} /$ $\mathrm{ml})$ and ${ }^{15} \mathrm{~N}$-Leu $(\mathrm{nmol} / \mathrm{ml})$ denote unlabeled, ${ }^{14} \mathrm{C}$ and ${ }^{15} \mathrm{~N}$ isotope leucine concentrations, respectively. The corresponding abbreviations are used for KIC. SA denotes specific activity $(\mathrm{dpm} / \mathrm{nmol})$; B indicates plasma flow $(\mathrm{ml} / \mathrm{min} \cdot 100 \mathrm{ml}$ of forearm). $[\mathrm{x}]$ corresponds to the ratio: $\left[{ }^{15} \mathrm{~N}-\mathrm{Leu}_{\mathrm{ven}}\right] /\left[{ }^{15} \mathrm{~N}-\mathrm{Leu}_{\text {art }}\right]$, i.e., it is the fraction of arterial ${ }^{15} \mathrm{~N}$-leucine delivery to forearm that is not metabolized. [y] corresponds to the ratio: $\left[{ }^{14} \mathrm{C}-\mathrm{Leu}_{\mathrm{ven}}\right] /$ $\left[{ }^{14} \mathrm{C}-\mathrm{Leu}_{\mathrm{art}}\right]$, i.e., the fraction of arterial ${ }^{14} \mathrm{C}$-leucine delivery that is not metabolized plus re-entry of tracer through ${ }^{14} \mathrm{C}-\mathrm{KIC}$ reamination. $[\mathrm{V}-\mathrm{A}]{ }^{14} \mathrm{CO}_{2}$ indicates the difference: [deep venousarterial ${ }^{14} \mathrm{C}$-bicarbonate concentration $(\mathrm{dpm} / \mathrm{ml})$. The notation [f] denotes transport rates of the ${ }^{14} \mathrm{C}$-tracers (in $\mathrm{dpm} / \mathrm{min}$. $100 \mathrm{ml}$ of forearm).

At steady state, the sum of entries into each compartment, (or sum of compartments considered together), must be equal to the sum of exits from the compartments13 (or sum of compartments, respectively). This is true for both the unlabeled and the labeled moieties (see below). Therefore, mass-balance equations can be used.

Given these assumptions and definitions, all the $\mathrm{F}$ and $\mathrm{f}$ transport rates can be solved using the following equations.

${ }^{14} \mathrm{C}$-Tracer model:

(1) $\mathrm{f} 1={ }^{14} \mathrm{C}-\mathrm{Leu}_{\mathrm{art}} \cdot \mathrm{B}$

(2) $\mathrm{f} 2=\mathrm{f} 1 \cdot(1-\mathrm{x})$

(3) $\mathrm{f} 3=\mathrm{f} 2+\mathrm{f} 4-\mathrm{f} 1$

(4) $\mathrm{f} 4={ }^{14} \mathrm{C}-\mathrm{Leu}_{\mathrm{ven}} \cdot \mathrm{B}$

(5) $\mathrm{f} 6=\mathrm{f} 2+\mathrm{f} 8-\mathrm{f} 7-\mathrm{f} 3$

(6) $\mathrm{f} 7=\mathrm{f} 8+\mathrm{f} 9+\mathrm{f} 11-\mathrm{f} 10$

(7) $\mathrm{f} 8=\mathrm{f} 4 \cdot(\mathrm{z}-\mathrm{x})$

(8) $\mathrm{f} 9=\left([\mathrm{V}-\mathrm{A}]{ }^{14} \mathrm{CO}_{2}\right) \cdot \mathrm{B}$

(9) $\mathrm{f} 10={ }^{14} \mathrm{C}-\mathrm{KIC}_{\text {art }} \cdot \mathrm{B}$

(10) $\mathrm{f} 11={ }^{14} \mathrm{C}-\mathrm{KIC}_{\text {ven }} \cdot \mathrm{B}$

(11) $\mathrm{f} 12=\mathrm{f} 1-\mathrm{f} 2$

Tracee model:

(12) $\mathrm{F} 1=\mathrm{Leu}_{\mathrm{art}} \cdot \mathrm{B}$

(13) $\mathrm{F} 2=\mathrm{f} 2 / \mathrm{Leu}_{\mathrm{art}} \mathrm{SA}$
(14) $\mathrm{F} 3=\mathrm{F} 2+\mathrm{F} 4-\mathrm{F} 1$

(15) $\quad \mathrm{F} 4=\mathrm{Leu}_{\mathrm{ven}} \cdot \mathrm{B}$

(16) $\mathrm{F} 5=\mathrm{F} 4+\mathrm{F} 6+\mathrm{F} 7-\mathrm{F} 1-\mathrm{F} 8$

(17) $\mathrm{F} 6=\mathrm{f6} / \mathrm{KIC}_{\mathrm{ven}} \mathrm{SA}$

(18) $\mathrm{F} 7=\mathrm{f} 7 / \mathrm{KIC}_{\mathrm{ven}} \mathrm{SA}$

(19) $\mathrm{F} 8=\mathrm{f} 8 / \mathrm{KIC}_{\mathrm{ven}} \mathrm{SA}$

(20) $\mathrm{F} 9=\mathrm{f} 9 / \mathrm{KIC}_{\mathrm{ven}} \mathrm{SA}$

(21) $\quad \mathrm{F} 10=\mathrm{KIC}_{\mathrm{art}} \cdot \mathrm{B}$

(22) $\mathrm{F} 11=\mathrm{KIC}_{\mathrm{ven}} \cdot \mathrm{B}$

(23) $\mathrm{F} 12=\mathrm{F} 1-\mathrm{F} 2$

Leucine net balance $(\mathrm{NB})$ is then calculated as:

(24) Leu NB = F5 - F6

\section{Acknowledgments}

Dr. Noemi Dussini (Dept. of Pediatrics, University of Padova, Italy) is acknowledged for plasma amino acid analysis.

This study was in part supported by Grants from the Italian National Research Council (CNR) (Target Project Biotechnology and Bioinstrumentation; grant 93.04691, and grant 94.02923).

\section{References}

1. Young, V.R. 1987. 1987 McCollum Award Lecture. Kinetics of human amino acid metabolism: nutritional implications and some lessons. Am. J. Clin. Nutr. 46:709-725.

2. Millward, D.J., and J.P.W. Rivers. 1989. The need for indispensable amino acids: the concept of the anabolic drive. Diabetes Metab. Rev. 5:191-212.

3. Beaufrere, B., F.F. Horber, W.F. Schwenk, H.M. Marsh, D.E. Matthews, J.E. Gerich, and M.W. Haymond. 1989. Glucocorticoids increase leucine oxidation and impair leucine balance in humans. Am. J. Physiol. 257:E712-E721.

4. Horber, F.F., and M.W. Haymond. 1990. Human growth hormone prevents the protein catabolic side effects of prednisone in humans. J. Clin. Invest. 86: 265-272.

5. Motil, K.J., D.E. Matthews, D.M. Bier, J.F. Burke, H.N. Munro, and V.R. Young. 1981. Whole body leucine and lysine metabolism: response to dietary protein intake in young men. Am. J. Physiol. 240:E712-E721.

6. Rennie, M.J., R.H.T. Edwards, D. Halliday, D.E. Matthews, S.L. Wolan, and D.J. Millward. 1982. Muscle protein synthesis measured by stable isotope techniques in man: the effects of feeding and fasting. Clin. Sci. 59:519-523.

7. Hoffer, L.J., R.D. Yang, D.E. Matthews, B.R. Bistrian, D.M. Bier, and V.R. Young. 1985. Effects of meal consumption on whole body leucine and alanine kinetics in young adult man. Br. J. Nutr. 53:31-38.

8. Tessari, P., G. Pehling, S.L. Nissen, J.E. Gerich, J.F. Service, R.A. Rizza, and M.W. Haymond. 1988. Regulation of whole body leucine metabolism with insulin during mixed meal absorption in normal and diabetic humans. Diabetes. 37:512-516.

9. Biolo, G., P. Tessari, S. Inchiostro, D. Bruttomesso, C. Fongher, L. Sabadin, M.G. Fratton, A. Valerio, and A. Tiengo. 1992. Leucine and phenylalanine kinetics during mixed meal ingestion. A multiple tracer approach. Am. J. Physiol. 262:E455-E463.

10. Young, V.R., C. Gucalp, W.M. Rand, D.E. Matthews, and D.M. Bier. 1987. Leucine kinetics during three weeks at submaintenance-to-maintenance intakes of leucine in men: adaptation and accomodation. Hum. Nutr. Clin. Nutr. 41C:1-18.

11. De Feo, P. F.F. Horber, and M.W. Haymond. 1992. Meal stimulation of albumin synthesis: a significant contributor to whole body protein synthesis in humans. Am. J. Physiol. 263:E794-E799.

12. Waterlow, J.C., P.J. Garlick, and D.J. Millward. 1978. Protein turnover in mammalian tissues and in the whole body. North Holland Publishing Co., Amsterdam/New York/Oxford. 117-132.

13. Welle, S., C. Thornton, M. Statt, and B. McHenry. 1994. Postprandial and whole body protein synthesis in young and old human subjects. Am. J. Physiol. 267:E599-E604.

14. McNurlan, M.A., P. Essen, E. Milnie, E. Vinnars, P.J. Garlick, and J. Wernerman. 1993. Temporal responses of protein synthesis in human skeletal muscle to feeding. Br. J. Clin. Nutr. 69:117-126. 
15. Gelfand, R.A., and E.J. Barrett. 1987. Effect of physiologic hyperinsulinemia on skeletal muscle protein synthesis amd breakdown in man. J. Clin. Invest. 80:1-6.

16. Louard, R.J., D.A. Fryburg, R.A. Gelfand, and E.J. Barrett. 1992. Insulin sensitivity of protein and glucose metabolism in human forearm skeletal muscle. J. Clin. Invest. 90:2348-2354.

17. Tessari, P., S. Inchiostro, G. Biolo, E. Vincenti, and L. Sabadin. 1991. Effects of acute systemic hyperinsulinemia on forearm muscle proteolysis in healthy man. J. Clin. Invest. 88:27-33.

18. Heslin, M.J.E., E. Newman, R.F. Wolf, and P.W.T. Pisters. 1992. Effect of hyperinsulinemia on whole body and skeletal muscle leucine carbon kinetics in humans. Am. J. Physiol. 262:E911-E918.

19. Arfviddsson, B., H. Zachrisson, A.C. Möller-Loswick, A. Hyltander, R. Sandström, and K. Lundholm. 1991. Effect of systemic hyperinsulinemia on amino acid flux across human legs in postabsorptive state. Am. J. Physiol. 260:E46-E52.

20. Nair, K.S., H.P. Schwartz, and S. Welle. 1982. Leucine as a regulator of whole body and skeletal muscle protein metabolism in humans. Am. J. Physiol. 263:E929-E934.

21. Barrett, E.J., J.H. Revkin, L.H. Young, B.L. Zaret, and R.A. Gelfand. 1987. An isotopic method for measurement of muscle protein synthesis and degradation in vivo. Biochem. J. 245:223-228.

22. Rosenberg, L.E., and C.R. Scriver. 1980. Disorders of amino acid metabolism. In Metabolic Control and Disease. P.K. Bondy and L.E. Rosenberg, editors. W.B. Saunders \& Co., Philadelphia. 707-710.

23. Harper, A.E., L.L. Miller, and K.P. Block. 1984. Branched-chain amino acid metabolism. Annu. Rev. Nutr. 4:409-454.

24. Krebs, H.A., and P. Lund. 1977. Aspects of the regulation of the metabolism of branched chain amino acids. Adv. Enzyme Regul. 15:375-394.

25. Cheng, K.N., F. Dworzak, G.C. Ford, M.J. Rennie, and D. Halliday. 1985. Direct determination of leucine metabolism and protein breakdown in humans using L- $\left[1-{ }^{13} \mathrm{C},{ }^{15} \mathrm{~N}\right]$ leucine and the forearm model. Eur. J. Clin. Invest. 15:349-353. 26. Bennet, W.M., A.A. Connacher, C.M. Scrimgeour, and M.J. Rennie. 1990. The effect of amino acid infusion on leg protein turnover assessed by $\mathrm{L}-\left[{ }^{15} \mathrm{~N}\right]$ phenylalanine and L- $\left[{ }^{13} \mathrm{C}\right]$ leucine exchange. Eur. J. Clin. Invest. 20:37-46. 27. Tessari, P.S. Inchiostro, M. Zanetti, and R. Barazzoni. 1995. A model of skeletal muscle leucine kinetics measured across the human forearm. Am. J. Physiol. 269:E127-E136.

28. Aoki, T.T., W.A. Muller, M.F. Brennan, and G.F. Cahill. 1973. Blood cell and plasma amino acid levels across forearm muuscle during a protein meal. Diabetes. 22:768-775.

29. Tizianello, A, G. DeFerrari, G. Garibotto, G. Gurreri, and C. Robaudo. 1980. Renal metabolism of amino acids and ammonia in subjects with normal renal function and in patients with chronic renal insufficiency. J. Clin. Invest. 65: $1162-1173$.

30. Classic, K.L., W.F. Schwenk, and M.W. Haymond. 1985. Radiobiological half-lives for carbon 14 and hydrogen 3 leucine in man. In Proceedings of the "Fourth International Radiopharmaceutical Dosimetry Symposium." A.T. Schlafke-Stelson and E.C. Watson, editors. Oak Ridge, TN. 681-687.

31. Andres, R.K., L. Zierler, H.M. Anderson, W.N. Stainsby, G. Cader, A.S. Ghrayyib, and J.L. Lilienthal. 1954. Measurement of blood flow and volume in the forearm of man: with note on the theory of indicator-dilution and of production of turbolence, hemolysis and vasodilatation by intravascular injection. J. Clin. Invest. 33:482-504.

32. Horber, F.F., J. Kahl, L. Lecavalier, B. Krom, and M.W. Haymond. 1989. Determination of leucine and $\alpha$-ketoisocaproic acid concentrations and specific activity in plasma and of leucine specific activity in proteins using high performance liquid chromatography. J. Chromatogr. 495:81-94.

33. Tessari, P., S. Inchiostro, M. Vettore, M.C. Marescotti, G. Biolo. 1991. A fast HPLC method for the measurement of plasma concentration and specific activity of phenylalanine. Clin. Biochem. 24:425-428.

34. Hagenfeldt, L.A., A. Larsson, and R. Anderson. 1978. The $\tau$-glutamyl cycle and amino acid transport. N. Engl. J. Med. 299:587-590.

35. Schwenk, W.F., P.J. Berg, B. Beaufrere, J.M. Miles, and M.W. Haymond. 1984. Use of t-butyldimethylsilylation in the GC/MS analysis of physiologic compounds found in plasma using electron impact ionization. Anal. Biochem. 141:101-109.

36. Okamura, K., L. Wentzel, P. Williams, and P. Flakoll. 1991. The fixation of $\mathrm{CO}_{2}$ by the liver, gut, kidney and hindlimb in vivo. Diabetes. 40:195A-195A.

37. Hoerr, R.A., Y. Yong-Ming, D.A. Wagner, J.F. Burke, and V.R. Young. 1989. Recovery of ${ }^{13} \mathrm{C}$ in breath from $\mathrm{Na}-\mathrm{H}^{13} \mathrm{CO}_{3}$ infused by gut and vein: effect of feeding. Am. J. Physiol. 257:E257-E262.

38. Herbert, V., L. Kam-Seng, C.W. Gottlieb, and J. Bleicher. 1965. Coated charcoal immunoassay of insulin. J. Clin. Endocrinol. Metab. 25:1375-1384.

39. Faloona, G.R., and R.H. Unger. 1985. Glucagon. In Methods in Hormone Radioimmunoassy. B.M. Jaffe, and H.R. Behrmann, editors. Academic Press, New York. 317-330.

40. Schwenk, W.F., B. Beaufrere, and M.W. Haymond. 1985. Use of reciprocal pool specific activities to model leucine metabolism in humans. Am. J. Physiol. 249:E646-E650.

41. Wolfe, R.R. 1992. Radioactive and stable isotope tracers in biomedicine. In Principles and Practice of Kinetics Analysis. Wiley-Liss, New York. 69-70.

42. Stolwijk, J., and J.D. Hardy. 1966. Temperature regulation in man. A theo- retical study. Pfluegers Arch. Eur. J. Physiol. 291/2:129-162.

43. Bjorntorp, P., and L. Sjostrom. 1978. Carbohydrate metabolism in man. Speculation and some quantitative consideration. Metab. 27:1853-1863.

44. Wahren, J., P. Felig, and L. Hagenfeldt. 1976. Effect of protein ingestion on splanchnic and leg metabolism in normal man and in patients with diabetes mellitus. J. Clin. Invest. 57:987-999.

45. Cheng, K.N., P.J. Pacy, F. Dworzak, G.C. Ford, and D. Halliday. 1987. Influence of fasting on leucine and muscle protein metabolism across the human forearm determined using $\mathrm{L}-\left[1-{ }^{13} \mathrm{C},{ }^{15} \mathrm{~N}\right]$ leucine as the tracer. Clin. Sci. 73:241-246.

46. Biolo, G., R.Y. Declan Fleming, and R.R. Wolfe. 1995. Physiologic hyperinsulinemia stimulates protein synthesis and enhances transport of selected amino acids in human muscle. J. Clin. Invest. 95:811-819.

47. Kimball, S.R., K.E. Flaim, D.E. Peavy, and L.S. Jefferson. 1989. Protein metabolism. In Diabetes Mellitus, Theory and Practice. M. Ellemberg and M. Rifkin, editors. Elsevier, New York/Amsterdam/London. 41-50.

48. Mortimore, G.E., and A.R. Pösö. 1987. Intracellular protein catabolism and its control during nutrient deprivation and supply. Annu. Rev. Nutr. 7:539-564.

49. Watt, P.W., M.E. Corbett, and M.J. Rennie. 1992. Stimulation of protein synthesis in pig skeletal muscle by infusion of amino acids during constant insulin availability. Am. J. Physiol. 263:E453-E460.

50. Luzi, L., P. Castellino, D.C. Simonson, A.S. Petrides, and R.A. DeFronzo. 1990. Leucine metabolism in IDDM. Role of insulin and substrate availability. Diabetes. 39:38-48.

51. Heiling, V.J., P.J. Campbell, I.S. Gottesman, E. Tsalikian, B. Beaufrere, J.E. Gerich, and M.W. Haymond. 1993. Differential effects of hyperglycemia and hyperinsulinemia on leucine rate of appearance in normal humans. J. Clin. Endocrinol. Metab. 76:203-206.

52. Fukagawa, N.K., K.L. Minaker, J.W. Rowe, M.N. Goodman, D.E. Matthews, D.M. Bier, and V.R. Young. 1985. Insulin-mediated reduction of whole body protein breakdown. Dose-response effects on leucine metabolism. J. Clin. Invest. 76:2306-2311.

53. Tessari, P., S. Inchiostro, G. Biolo, R. Trevisan, G. Fantin, M.C. Marescotti, E. Iori, A. Tiengo, and G. Crepaldi. 1987. Differential effects of hyperinsulinemia and hyperaminoacidemia on leucine-carbon metabolism in vivo. Evidence for distinct mechanisms in regulation of net amino acid deposition. $J$. Clin. Invest. 79:1062-1069.

54. Castellino, P., L. Luzi, D.C. Simonson, M.W. Haymond, and R.A. DeFronzo. 1987. Effect of insulin and plasma amino acid concentration on leucine metabolism in man. Role of substrate availability on estimates of whole body protein synthesis. J. Clin. Invest. 80:1784-1793.

55. Bennet, W.M., A.A. Connacher, C.M. Scrimgeour, R.T. Jung, and M.J. Rennie. 1990. Euglycemic hyperinsulinemia augments amino acid uptake by human leg tissues during hyperaminoacidemia. Am. J. Physiol. 259:E185-E194. 56. Tyobeka, E.M., and K.L. Manchester. 1985. Control of cell-free protein synthesis by amino acids: effects on tRNA charging. Int. J. Biochem. 17:973-977.

57. Douglas, R.G., P.D. Gluckman, K. Ball, B. Breier, and J.H. Shaw. 1991. The effects of infusion of insulinlike growth factor (IGF) I, IGF-II, and insulin on glucose and protein metabolism in fasted lambs. J. Clin. Invest. 88:614-622.

58. Fryburg, D.A., R.A. Gelfand, and E.J. Barrett. 1991. Growth hormone acutely stimulates forearm muscle protein synthesis in normal humans. Am. J. Physiol. 260:E499-E504

59. Fryburg, D.A., L.A. Jahn, S.A. Hill, D.M. Oliveras, and E.J. Barrett. 1995 Insulin and insulin-like growth factor-I enhance human skeletal muscle protein anabolism during hyperaminoacidemia by different mechanisms. J. Clin. Invest. 96:1722-1729.

60. Thissen, J.P., J.M. Ketelslegers, and L.E. Underwood. 1994. Nutritional regulation of the insulin-like growth factors. Endocr. Rev. 15:80-101.

61. Biolo, G, S.P. Maggi, B.D. Williams, K.D. Tipton, and R.R. Wolfe. 1995. Increased rates of muscle protein turnover and amino acid transport after resistance exercise in humans. Am. J. Physiol. 268:E514-E520.

62. Watt, P.W., Y. Lindsay, C.M. Scrimgeour, P.A.F. Chein, J.N.A. Gibson, D.J. Taylor, and M.J. Rennie. 1991. Isolation of aminoacyl t-RNA and its labeling with stable-isotope tracers: use in studies of human protein synthesis. Proc. Natl. Acad. Sci. 88:5892-5896.

63. Quinn Baumann, P., W.S. Stirewalt, B.D. O'Rourke, D. Howard, and S.K. Nair. 1994. Precursor pools of protein synthesis: a stable isotope study in a swine model. Am. J. Physiol. 267:E203-209.

64. Horber, F.F., C.M. Horber-Feyder, S. Krayer, W.F. Schwenk, and M.W. Haymond. 1989. Plasma reciprocal pool specific activity predicts that of intracellular free leucine for protein synthesis. Am. J. Physiol. 257:E385-E399.

65. Layman, D.K., and R.R. Wolfe. 1987. Sample site selection for tracer studies applying a unidirectional circulatory approach. Am. J. Physiol. 253:E173-E179.

66. Matthews, D.E., D.M. Bier, M.J. Rennie, R.H.T. Edwards, D. Halliday, D.J. Millward, and G.C. Clugston. 1981. Regulation of leucine metabolism in man: a stable isotope study. Science (Wash. DC). 214:1129-1131.

67. Felig, P.J. Wahren, and L. Räf. 1973. Evidence for inter-organ amino acid transport by blood cells in humans. Proc. Natl. Acad. Sci. USA. 70:1775-1779.

68. Cooper, K., O. Edholm, and R. Mottram. 1955. The blood flow in skin and muscle in the human forearm. J. Physiol. (Lond). 128:258-267.

69. Biolo, G., A. Gastaldelli, X.J. Zhang, and R.R. Wolfe. 1994. Protein synthesis and breakdown in skin and muscle: a leg model of amino acid kinetics. Am. J. Physiol. 267:E467-E474. 